\title{
KRAS Mutant Pancreatic Cancer: No Lone Path to an Effective Treatment
}

\author{
Daniel Zeitouni, Yuliya Pylayeva-Gupta, Channing J. Der * and Kirsten L. Bryant \\ Lineberger Comprehensive Cancer Center, University of North Carolina at Chapel Hill, Chapel Hill, NC 27599, \\ USA; dzeitoun@live.unc.edu (D.Z.); yuliyap1@email.unc.edu (Y.P-G.); bryantk1@email.unc.edu (K.L.B.) \\ * Correspondence: cjder@med.unc.edu; Tel.: +1-919-966-5634
}

Academic Editor: Jonas Cicenas

Received: 23 February 2016; Accepted: 11 April 2016; Published: 18 April 2016

\begin{abstract}
Pancreatic ductal adenocarcinoma (PDAC) is among the deadliest cancers with a dismal $7 \%$ 5-year survival rate and is projected to become the second leading cause of cancer-related deaths by 2020. KRAS is mutated in 95\% of PDACs and is a well-validated driver of PDAC growth and maintenance. However, despite comprehensive efforts, an effective anti-RAS drug has yet to reach the clinic. Different paths to inhibiting RAS signaling are currently under investigation in the hope of finding a successful treatment. Recently, direct RAS binding molecules have been discovered, challenging the perception that RAS is an "undruggable" protein. Other strategies currently being pursued take an indirect approach, targeting proteins that facilitate RAS membrane association or downstream effector signaling. Unbiased genetic screens have identified synthetic lethal interactors of mutant RAS. Most recently, metabolic targets in pathways related to glycolytic signaling, glutamine utilization, autophagy, and macropinocytosis are also being explored. Harnessing the patient's immune system to fight their cancer is an additional exciting route that is being considered. The "best" path to inhibiting KRAS has yet to be determined, with each having promise as well as potential pitfalls. We will summarize the state-of-the-art for each direction, focusing on efforts directed toward the development of therapeutics for pancreatic cancer patients with mutated KRAS.
\end{abstract}

Keywords: RAS; pancreatic; cancer; therapeutics

\section{Mutant KRAS Drives PDAC Development and Maintenance}

Approximately $90 \%$ of pancreatic cancers are pancreatic ductal adenocarcinoma (PDAC), which is almost universally fatal [1]. Major advancement in the treatment of PDAC has been lacking [2]. Currently, surgery remains the lone curative option. To be eligible for surgery with curable intent the tumor must be resectable, meaning there are no signs of distant metastasis [3]; however, most patients are diagnosed with late-stage disease, and hence less than $20 \%$ of patients are eligible. Recent exome sequencing has provided a detailed genetic profile of PDAC, with mutational activation of the KRAS oncogene found in $\sim 95 \%$ of patients [4-7]. With significant and compelling evidence that aberrant KRAS protein function is critical for PDAC growth and maintenance [8-10], the Pancreatic Cancer Working Group (NCI) identified targeting KRAS as one of four key priorities for pancreatic cancer research [11]. However, despite more than three decades of intensive effort, an effective anti-RAS therapy has yet to reach the clinic [12-14].

The RAS family of small GTPases includes three genes: HRAS, NRAS, and KRAS. These three loci encode four different protein isoforms: HRAS, NRAS, KRAS4A, and KRAS4B. The two KRAS isoforms differ due to the alternative splicing of exon 4 in the KRAS locus, with KRAS4B being the predominant isoform expressed in most tissues [15]. Each RAS protein is comprised of two major domains, the $\mathrm{G}$ domain and the membrane targeting domain (Figure 1). All of the isoforms are similar in the amino acid sequence of the $\mathrm{G}$ domain $(\sim 80 \%)$ with major differences being restricted to the 
hypervariable region of their C-terminal domains [16]. Mutations in RAS occur in residues 12, 13 and 61, and inhibit GTP hydrolysis activity [17]. The three $R A S$ genes constitute the most frequently mutated oncogene family in human cancers [14,18]; however, the specific isoform and amino acid mutation varies among cancers. Mutations in HRAS are most frequently found in melanoma, bladder and mammary carcinoma; NRAS mutations are found in melanoma and thyroid carcinoma; and KRAS mutations are most prevalent in cancers of the bladder, ovary, thyroid, lung, colon and pancreas. In pancreatic cancer, mutations in codon 12 of KRAS occur the most frequently.

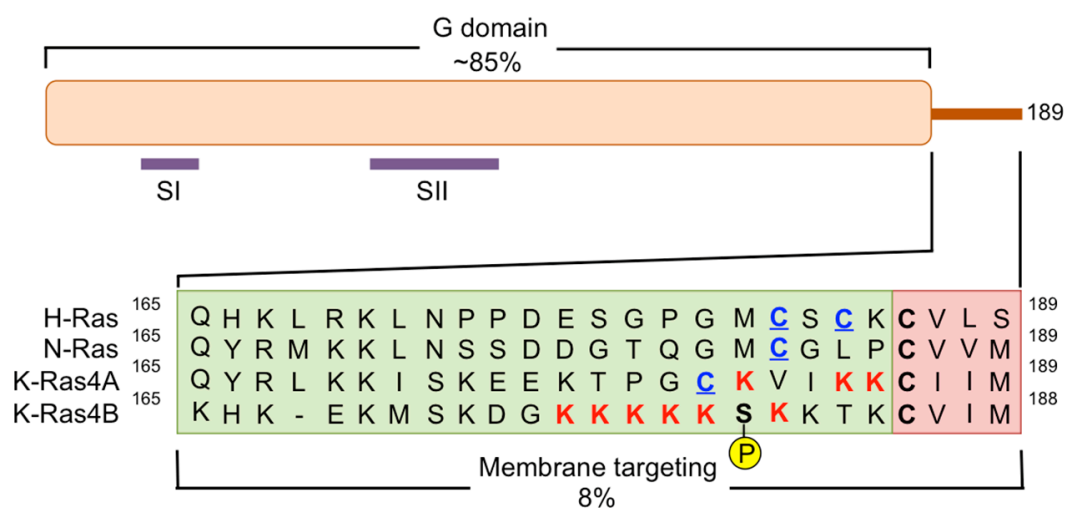

C Pamitoylated cysteine

(P) Phosphate

Figure 1. Human RAS proteins are composed two functional domains, the G domain and the membrane targeting domain. The G domain spans residues 1-164 and includes the regions of the protein responsible for binding and hydrolyzing GTP. Specifically, residues in the switch I (SI = amino acids 30-38) region and switch II (SII = amino acids 60-76) region experience a conformational change during GDP-GTP cycling. The membrane targeting domain is comprised of the remaining 24/25 C-terminal residues. The first 20-21 amino acids are referred to as the hypervariable region and this is where the three RAS isoforms exhibit the greatest diversity in protein sequence. The hypervariable region contains elements important for membrane association including cysteines (blue, underlined) that are covalently modified by the addition of a palmitate fatty acid, and stretches of polybasic amino acids. Additionally KRAS4B contains a serine (181) that can be phosphorylated and regulates the association of this protein with the plasma membrane or endomembranes. The four most C-terminal residues of the membrane-targeting domain comprise the CAAX motif, where $\mathrm{C}=$ cysteine, $\mathrm{A}=$ any aliphatic residue, and $\mathrm{X}=$ the terminal amino acid. A C15 farnesyl group is covalently attached to the cysteine residue by farnesyltransferases and this lipid moiety aids in membrane association.

RAS proteins play an active role in cell differentiation, proliferation, migration, and apoptosis, making them important in cancer signaling [19]. Individual RAS proteins are activated when they are bound to guanosine triphosphate (GTP) and are inactive when they are bound to guanosine diphosphate (GDP) (Figure 2). Intrinsic RAS GTP-GDP cycling is regulated by guanine nucleotide exchange factors (GEFs) that stimulate nucleotide exchange and by GTPase activating proteins (GAPs) that accelerate the intrinsic GTP hydrolysis activity of RAS (Figure 2). Once activated, RAS-GTP preferentially interacts with a spectrum of catalytically diverse downstream effectors that then regulate a myriad of cytoplasmic signaling networks. 

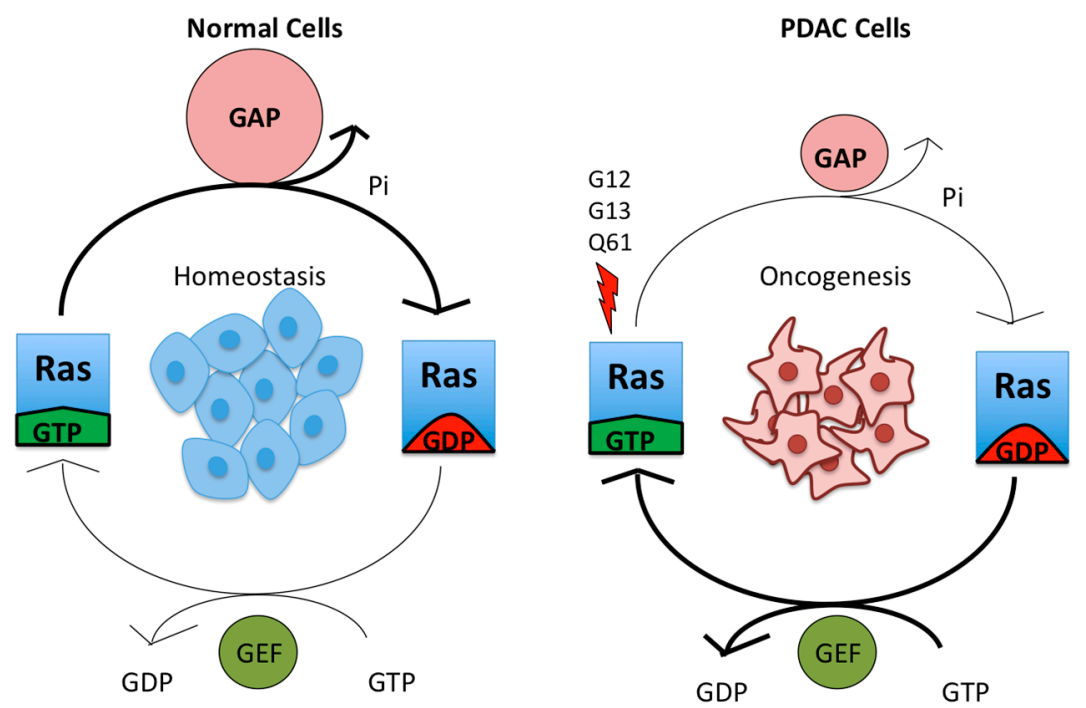

Figure 2. Mutant KRAS is continuously in a GTP-bound, active state. Wild-type KRAS cycles between an active, GTP-bound and an inactive, GDP-bound state, and it exists largely in an inactive state in non-dividing cells. Upon growth factor stimulation, normal KRAS is activated by RAS guanine nucleotide exchange factors (RASGEFs), which facilitate the binding of GTP to KRAS. KRAS-GTP then binds downstream effectors. This signaling is attenuated due to the action of RAS GTPase-activating proteins (RASGAPs), which promote the hydrolysis of the bound GTP to GDP and hence formation of inactive KRAS-GDP. Mutation of residues G12, G13 or Q61 constitutively activates KRAS by preventing the formation of van der Waals interactions between RAS and RASGAPs [20] and interfering with the position of a water molecule necessary for GTP hydrolysis [21], respectively. The arrow thickness and relative size of the symbols for GEFs and GAPs indicate the level of signaling.

KRAS mutation is the initiating genetic event for PDAC, with KRAS mutations found in $~ 95 \%$ of pancreatic intraepithelial neoplasias (PanINs), the earliest pre-neoplastic stages of pancreatic cancer progression [22,23]. Progression to invasive, malignant PDAC involves a step-wise accumulation of additional genetic alterations, in particular, the inactivation of tumor suppressor genes [24]. Loss of the cyclin-dependent kinase inhibitor 2A (CDKN2A) tumor suppressor gene function by mutation or promoter methylation is found in $95 \%$ of pancreatic tumors [25]. CDKN2A encodes p16/Ink4a and p14/Arf, inhibitors of cyclin-dependent kinases 4 and 6 (CDK4/6) and MDM2-mediated p53 tumor suppressor degradation, respectively. CDK4/ 6 hyperactivation in turn inactivates the RB tumor suppressor, promoting tumor progression. Later stage steps involve missense, loss-of-function mutations in TP53 and the SMAD4 tumor suppressor genes. TP53 is mutated in 75\% of PDAC. Smad4 functions as a downstream component of the tumor growth factor $\beta$-signaling network. In pancreatic cancer, a mutation in Smad4 is often associated with metastatic disease [26].

KRAS plays a vital role in PDAC and is believed to be a key target for treatment. Decades of research have shaped our understanding of the biochemistry, structure, and cellular signaling of KRAS in cancer. This foundation of knowledge can be viewed in two ways: support for the need to find different routes to silence KRAS, or fodder for the notion that KRAS is "undruggable". In this review, the most promising paths taken in an attempt to suppress the effects of KRAS in cancer are discussed. We will examine efforts to target KRAS directly, prevent KRAS from binding to cellular membranes, inhibit its downstream effectors, search for synthetic lethal interactors of mutant KRAS, disrupt the metabolic pathways KRAS regulates, and exploit the ways KRAS signaling influences the tumor microenvironment (Figure 3). 


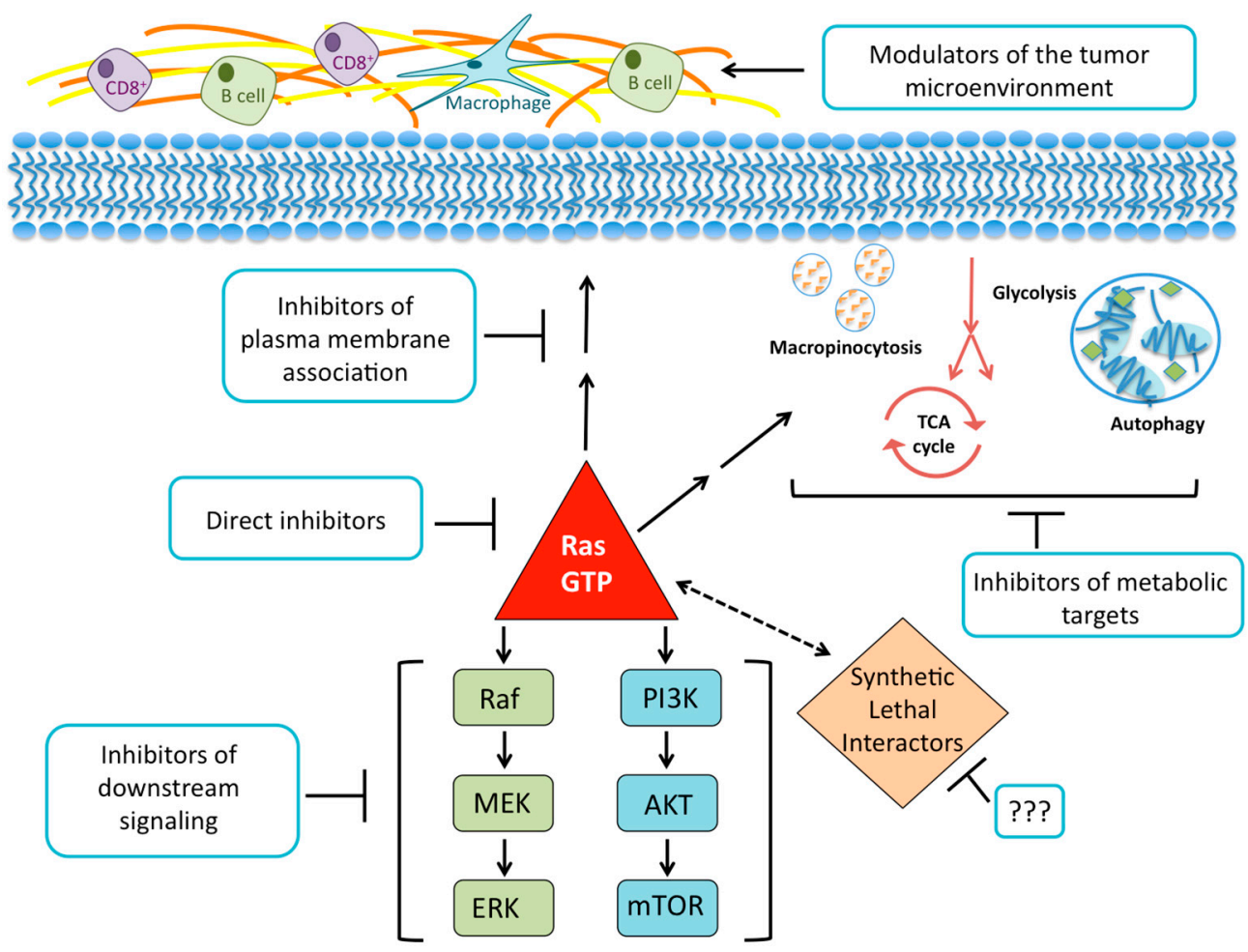

Figure 3. The current paths in the pursuit of an anti-KRAS therapy. There have been past and ongoing efforts to synthesize molecules that bind directly to the RAS protein and inhibit its GDP-GTP regulation or effector signaling. Disrupting RAS membrane localization by inhibiting farnesylation showed promising preclinical effects but no anti-tumor activity in clinical trials. Attempts to inhibit downstream effector signaling have generated a large number of inhibitors currently under clinical evaluation. Unbiased genetic functional RNAi screens have identified genes that may act as synthetic lethal interactors. However, these studies have been limited by reproducibility or the transition of hits to a therapeutic strategy. The broken line represents the functional relationship in the absence of a linkage via a specific signaling network. The elucidation of the many metabolic processes that $K R A S$ regulates may result in new therapies for patients with PDAC. Likewise, the discovery of ways to degrade the dense stroma associated with PDAC tumors and employ the immune response may lead to novel therapies for PDAC.

\section{Direct Inhibition of RAS}

Inhibiting RAS directly is the most obvious approach and arguably the most attractive for developing a treatment for KRAS mutant PDAC. Since a treatment aimed at targeting all RAS isoforms would be deleterious to normal as well as neoplastic tissue, studies have focused on specifically targeting KRAS. Unfortunately, RAS activation and signaling is accomplished primarily through protein-protein interactions and such interfaces have traditionally been difficult to target with small molecules because they lack well-defined binding pockets [27]. Although some deemed KRAS "undruggable", recent data have revived the hope to target RAS directly.

The first small molecules identified as direct binders that altered RAS function targeted the site on RAS involved in its recognition by the RASGEF, SOS1. SOS1 catalyzes the exchange of GDP to GTP, the rate-limiting step in RAS activation, and thus regulates RAS activity. Fragment-based lead discovery (FBLD) provided a starting point to finding compounds that bind to RAS targets, leading to the discovery of small molecules that bound to KRAS GDP and inhibited SOS-mediated nucleotide exchange [28]. Independently, a second group identified small molecules that bind to RAS and also inhibit SOS1-catalyzed nucleotide exchange [27]. These small molecules bind to the hydrophobic pocket on the CDC25 domain of SOS. The structure not only demonstrated how these 
small molecules bind, but also revealed other potential binding sites that have yet to be targeted by existing compounds [29].

Shortly after, another study identified molecules that inhibited RAS protein-protein interactions, the Kobe0065-family compounds were found to bind to RAS-GTP and inhibit interactions with downstream effectors [30]. Shima et al. suggests that once these compounds are structurally optimized, they could be used to develop RAS inhibitors with the high potency and specificity, as well as the low toxicity necessary for clinical application [30].

A third class of RAS-binding small molecules was developed to selectively recognize the G12C missense mutant of KRAS [31]. Targeting the S-IIP binding site affects KRAS signaling through two mechanisms. It shifts the nucleotide affinity from GTP to GDP, which leads to more RAS molecules in the inactive state, and it diminishes interactions with effectors [31]. SML-8-73-1, a GDP analogue has been developed to specifically target cancers with a KRAS ${ }^{\mathrm{G} 12 \mathrm{C}}$ mutation. SML-8-73-1 competes with GTP and GDP for active site binding and treatment with SML-8-73-1 stabilizes an inactive form of KRAS [32]. Although SML-8-73-1 can penetrate the cell membrane, it requires high concentrations, which may result in a loss of selectivity and potential off-target activities. Although the KRAS ${ }^{\mathrm{G} 12 \mathrm{C}}$ mutation is prevalent in non-small-cell lung cancer, this mutation is rarely found in PDAC (3\%) [14]. To date, mutation specific compounds targeting the more common KRAS G12D or G12V mutations have yet to be developed.

Using RNA interference (RNAi) to suppress KRAS expression has been validated as therapeutic strategy in RAS mutant-driven mouse models of cancer [33,34]. RNAi mediated suppression of expression of mutant $K R A S$ in pancreatic cancer cells reduced proliferation, anchorage-independent growth, and tumorigenic growth [10,35]. The effects of KRAS siRNA on PDAC suggest that RNAi can be explored as a potential drug for KRAS mutant PDAC [36]; however, the delivery of siRNA in vivo is a challenge because of enzymatic breakdown, renal clearance, and precise targeting to the tissue of interest. Improved delivery methods have been developed, such as a Local Drug EluteR, (LODER), a miniature biodegradable polymetric matrix that protects the siRNA and enables stable, local release of the siRNA for months within the tumor tissue [37]. Using this technology, delivery of KRAS ${ }^{\mathrm{G} 12 \mathrm{D}}$-specific siRNA clearly dampened KRAS expression and inhibited the in vivo growth of pancreatic tumors in both subcutaneous and orthotopic mouse models [37]. A clinical phase I/IIa study of siG12D-LODER in combination with chemotherapy was recently completed in patients with locally advanced PDAC [38]. The LODER was inserted into the tumor using a standard endoscope ultrasound biopsy and was thus able to provide local, continuous treatment in the tumor for several months. The treatment was given in combination with FOLFIRINOX, a standard of care chemotherapy cocktail commonly used in advanced pancreatic cancer patients in good health, and was tolerated well [38]. The results of the combination treatment showed a median overall survival of 15.13 months, and a median time to metastasis of 8.25 months [38]. A drawback to this technology is the LODER must be directly implanted in the tumor. Pecot et al. achieved systemic in vivo delivery of KRAS-targeting siRNA using a nanoliposomal delivery platform made of 1,2-dioleoyl-sn-glycero-3-phosphatidylcholine (DOPC). Mice with KRAS mutant lung cancer treated with the DOPC-mediated siRNA showed decreased downstream signaling, inhibited proliferation, and a decrease in metastatic burden in vivo [39]. Finally, since wild type and mutant $R A S$ differ by just one missense mutation, an additional challenge is the development of siRNA that targets the mutant gene selectively.

\section{Disruption of RAS Plasma Membrane Localization}

RAS must be positioned at the inner face of the cell membrane to be biologically active, and the CAAX motif, located on all RAS isoforms, is both necessary and sufficient for a series of post-translational modifications that facilitate its membrane association $[16,40]$. Therefore, an attractive target for anti-RAS inhibitors is the prevention of post-translational lipid modification and membrane binding. The CAAX box of synthesized RAS proteins undergoes a series of modifications, the first step being the farnesyltransferase (FTase)-mediated covalent addition of a 15-carbon (C15) 
farnesyl isoprenoid to the cysteine of the CAAX-motif. Next, RAS-converting enzyme 1 (RCE1) catalyzes the proteolytic removal of the AAX peptide, and finally isoprenylcysteine methyltransferase (ICMT) catalyzes the carboxylmethylation of the now terminal farnesylated cysteine. Pharmacological inhibitors of all three CAAX-modifying enzymes have been developed, but FTase has been the most favored target since it is the first step of the three modifications [14]. Preclinical cell culture and mouse model studies showed farnesyl transferase inhibitors (FTIs) are potent, non-toxic inhibitors of HRAS-driven growth in vitro and in vivo. FTIs can also block the farnesylation and membrane association of the RAS isoforms more commonly mutated in cancer (KRAS and NRAS); however, when FTase activity is blocked, these RAS isoforms can undergo modification by a related lipid geranylgeranyl transferase enzyme (GGTase-I), overcoming the actions of FTI treatment. A logical solution to this limitation of FTIs is the use of GGTIs in combination treatment with FTI. However, since there may be up to 300 additional substrates of FTase and GGTase-I aside from RAS proteins, off-target effects are a concern for normal tissue toxicity in vivo.

Clinical trials of FTIs to treat PDAC and other cancers with prevalent KRAS mutations did not show significant anti-tumor activity or impact on patient survival [41,42]. A phase II study of tipifarnib in patients with surgically incurable or advanced PDAC showed no benefit [43]. The problem was initially thought to be the dose of tipifarnib, but further studies demonstrated that the dose was appropriate as inhibition of farnesyl transferase in peripheral blood monocytes was observed [44]. Since higher doses could not be tolerated, the possibility of combination therapies was explored, but a Phase III study with the combination of tipifarnib and the cytotoxic chemotherapy gemcitabine showed no benefits [45].

Another strategy to prevent the interaction of the RAS farnesyl group with the cell membrane is the use of a farnesyl-cysteine mimetic that would compete with RAS proteins for association with RAS anchorage cites [46]. Farnesyl thiosalicylic acid (FTS/salirasib) inhibits RAS signaling, in part, by dislodging RAS from the cell membrane and rendering it susceptible to proteolytic degradation [47]. Salirasib showed some promise in mice, as salirasib treatment inhibited cell growth in HRAS transformed rat fibroblasts with drug concentrations that did not affect processes like farnesylation and carboxyl methylation [48]. While salirasib showed activity towards active RAS, it is certain that salirasib will have non-RAS targets. Salirasib has undergone phase II clinical trials in non-small cell lung carcinoma (NSCLC) patients with mutated KRAS. The monotherapy was determined to be insufficient at the current dose with modest toxicity, presenting another disappointing result [49].

The discovery of proteins that facilitate the trafficking of RAS to the plasma membrane has provided an alternative approach to interfering with RAS membrane association. Phosphodiesterase 6 delta $(\mathrm{PDE} \delta)$ is important for photoreceptor signaling and is responsible for the trafficking of the PDE6 complex (which contains farnesylated and geranylgeranylated substrates) [50]. PDE $\delta$ can also recognize KRAS4B and enhance its transit to the plasma membrane, and thus, interfering with the binding of PDE $\delta$ to KRAS provides an opportunity to disrupt RAS function [51]. Inhibition of the PDE $\delta$-KRAS interaction using small molecules provides an opportunity to suppress KRAS and effect pancreatic cancer tumor development. Deltarasin, which is a high affinity PDE $\delta$-KRAS interaction inhibitor, had a negative effect on the plasma membrane association of KRAS4B and reduced the growth of KRAS-dependent PDAC cell lines [51].

RAS controls many downstream pathways and this could be due to its compartmentalization in cells. In addition to the plasma membrane, RAS also signals from endosomes, the endoplasmic reticulum, the Golgi apparatus, and mitochondria. In T lymphocytes, the location of RAS signaling dictates the biological outcome [52]. Phosphorylation by protein kinase C (PKC) at serine 181 (S181) in the polybasic region of KRAS4B results in its release from the plasma membrane and accumulation of KRAS4B on internal membranes, representing a farnesyl-electrostatic switch [53]. After the switch is engaged, phospho-KRAS4B translocates from the cell membrane to the endoplasmic reticulum, Golgi apparatus and outer mitochondrial membrane [53]. This translocation is associated with 
antiproliferative effects as phospho-KRAS4B signaling through inositol-triphosphate receptors at the ER promotes cell death, suggesting a possible strategy for anti-RAS treatments [54].

Bryostatins are PKC agonists, and therefore are capable of triggering KRAS dissociation from the plasma membrane [55]. Mice bearing orthotopic tumors derived from the human pancreatic cancer cell line, KC1-MOH1 [56], responded very well to a combination of bryostatin-1 and gemcitabine with remission in only one of every seven animals [57]. However, to date, there have been more than 20 clinical studies using bryostatin-1 monotherapy or combination therapies in numerous different cancer types, and none have been successful [58]. In addition to not being clinically effective, there were toxic effects like myalgia, local phlebitis, fatigue, nausea, and thrombocytopenia [59]. Further studies determining the functionality of RAS based on its subcellular localization would be a critical step toward finding a drug that targets specific RAS pathways.

\section{Searching for Synthetic Lethal Interactors}

Synthetic lethality arises when a combination of mutations in two or more genes leads to cell death. Thus, synthetic lethal interactors of mutant RAS would be genes for which the loss of function would be lethal to the cell only in the presence of mutant RAS. The existence of oncogene-specific synthetic lethal interactions is supported by the notion that oncogenic transformation profoundly changes the phenotype of the cell $[60,61]$. Potential targets may exist is pathways that aid the RAS-transformed cell in coping with the cellular stress associated with persistent proliferation or the nutrient-supply pathways that fuel this proliferation. Several studies have identified synthetic lethal interactors with mutant KRAS through the use of RNAi screens in human cancer cell lines [62]; unfortunately, this first generation of screens yielded only new information about the biology of mutant KRAS-harboring cells, not new therapeutic targets.

The hits from screens for synthetic lethal interactors for mutant KRAS span many different cellular processes including: Cell cycle/mitosis, cell survival, gene transcription, and cell growth. Therapeutically, targeting cell cycle regulators such as survivin, CDK1 [63], or TPX2 [64] would most likely be similarly toxic to normal and neoplastic cells. Additionally, transcription factors such as GATA2 $[65,66]$ are largely considered undruggable. A potentially druggable hit, serine/threonine protein kinase 33 (STK33), was initially considered a tractable target [67]; however, follow-up studies have determined that both genetic depletion and pharmacological inhibition of STK33 has no effect on cell growth [68]. Likewise, genetic and pharmacological validation of the hit TBK1 [69] found no reproducible requirement for TBK1 in the growth of KRAS-mutant tumor cell lines in vitro [70].

There were a number of limitations with the first generation of mutant KRAS synthetic lethal screens that could be improved upon in future studies. First, many of these screens relied on isogenic matched pairs of cells lines harboring KRAS mutations, and a matched counterpart in which the KRAS allele is genetically ablated. Acute ablation of KRAS causes apoptosis and severe growth impairment [71], and thus proliferating cells that eventually arise must acquire additional, adaptive alterations and are therefore not truly isogenic. Currently, efforts are underway to screen large panels of cancer cell lines that are more representative of the heterogeneity that exists in human KRAS-mutant cancers. Additionally, all previously described screens have utilized in vitro anchorage-dependent culture conditions. Second generation screens would benefit from anchorage-independent culture systems, such as organoid cultures or in vivo xenograft tumor assays, which more accurately model tumor biology. Such methods have already been utilized in screens for other purposes [72-74]. Furthermore, the first generation screens serve as a reminder that as with any high-throughput approach, hits must be rigorously validated.

\section{Targeting RAS Downstream Signaling Pathways}

Eleven RAS effector families have been identified to date, with six of these families having validated roles in contributing to RAS-dependent cancer initiation and/or maintenance [17,75]. As directly targeting the RAS protein has proved challenging, currently the most favorable method 
for targeting RAS signaling is through targeting its downstream effectors' signaling. Herein, we will focus on the most intensely targeted pathways: the RAF-MEK-ERK mitogen-activated protein kinase (MAPK) cascade and the PI3K-AKT-mTOR cell-survival signaling pathway.

\subsection{RAF-MEK-ERK}

Active RAS can engage three highly related RAF serine/threonine kinases: ARAF, BRAF, and CRAF. The largely mutually exclusive frequency of $B R A F$ and $R A S$ mutations supports the notion that RAF is a critical driver in KRAS-mutant pancreatic cancer. RAS-GTP binds preferentially to RAF, resulting in the translocation of RAF to the plasma membrane where subsequent events promote its activation. Active RAF phosphorylates and activates the MEK1 and MEK2 dual specificity kinases, which in turn phosphorylate and activate ERK1 and ERK2 serine-threonine MAPKs. Activated ERKs phosphorylate a diverse spectrum of more than 200 cytoplasmic and nuclear substrates [76,77].

There are currently two BRAF-selective inhibitors in the clinic, vemurafenib and dabrafenib. Vemurafenib is approved for the treatment of $B R A F$-mutant melanoma. Vemurafenib proved effective in melanoma patients harboring $B R A F$ mutations with a response rate of greater than $50 \%$ and a rapid improvement in quality of life. Unexpectedly, when these RAF inhibitors were used in $R A S$-mutant cancers, activation rather than inactivation of ERK was observed [78-80]. This is due to the propensity of these first-generation RAF inhibitors to induce RAF dimerization, which causes activation of CRAF [81]. Recently, pan-RAF inhibitors have entered clinical evaluation [82]. This new class of inhibitors is not subject to the paradoxical activation seen with the BRAF-selective inhibitors, and may be more effective in $R A S$-mutant cancers $[83,84]$.

In addition to BRAF inhibitors for melanoma, MEK inhibitors have also be developed. Trametinib (GSK112021) is a selective allosteric inhibitor of MEK1/2 activation and kinase activity [85]. In a Phase III trial of patients with advanced or metastatic $B R A F^{V 600 E / K}$-positive melanoma, the response rate for the trametinib monotherapy was $22 \%$, but in combination with dabrafenib the response rate increased to $64 \%$ [85]. This combination therapy likely delays pathway alterations that lead to ERK reactivation and the resistance that occurs in response to BRAF or MEK monotherapy. While MEK inhibitors have shown success in the treatment of BRAF-mutant melanoma, they have shown limited efficacy in RAS-mutant human tumor cell lines [86] and RAS-driven mouse models of cancer [87]. A recent study suggests that the mechanism by which MEK is activated in $R A S$-versus BRAF-mutant cancers is different, thus explaining the different responses in different systems [88]. Resistance to MEK inhibitors in $R A S$-driven cancers occurs due to upregulation or amplification of upstream activators that restore ERK activity [82].

As dynamic kinome reprogramming [89] in response to RAF and MEK inhibitors eventually leads to increased ERK signaling in RAS-driven cancers, ERK has become an attractive target [81,82]. Four ERK inhibitors (BVD-523, MK8353, GDC-0994, and CC-90003) have entered Phase I studies, and MK8353 (an analog of SCH772984) has been described preclinically [90], where it showed promising results in BRAF- or MEK-inhibitor resistant cell line models [90]. Additionally, concurrent targeting of the RAF-MEK-ERK cascade at multiple nodes is currently under investigation as an effective strategy to achieve prolonged ERK suppression. A recent study focused on directly targeting ERK as a treatment for pancreatic cancer identified the degradation of the MYC oncoprotein and the induction of a senescence-like phenotype as the predominant growth suppression mechanism of ERK inhibitors [71]. This study also identified PI3K-AKT-mTOR signaling as a critical determinant of ERK inhibitor sensitivity, and PI3K, Notch, and p38 as potential modulators of ERK resistance [71]. This suggests that multiple inhibitor-based combinations will be necessary to treat across multiple KRAS-mutant PDAC populations.

\subsection{PI3K-AKT-mTOR}

The catalytic subunits of class I PI3K lipid kinases $(\alpha, \beta, \delta$ and $\gamma)$ comprise the second-best validated effector family critical for $R A S$-driven cancer growth. The gene encoding PI3K $\alpha(P I K 3 C A)$ 
is often mutationally activated in cancers, which supports its role as a cancer driver. PI3K signaling pathways are important for the regulation of cellular functions such as metabolism, growth, proliferation, survival, transcription and protein synthesis. Mutant RAS activates PI3K. Once PI3K is activated, it binds to $\mathrm{PIP}_{2}$ (phosphatidylinositol 4,5-bisphosphate), a component of the cell membrane and phosphorylates $\mathrm{PIP}_{2}$ to $\mathrm{PIP}_{3}$ (phosphatidylinositol 3,4,5-triphosphate), which in turn can regulate the activities of many signaling proteins, in particular the 3-phosphoinositide-dependent protein kinase-1 (PDPK1 or PDK1) and AKT serine/threonine kinase. Upon PIP ${ }_{3}$-dependent recruitment to the plasma membrane, AKT is phosphorylated by PDK1, which itself is associated with $\mathrm{PIP}_{3}$ at the plasma membrane. AKT promotes activation of the Rheb small GTPase, which then activates mTOR, a protein that is involved in growth factor signaling, the energy state of the cell, and nutrient and oxygen availability.

There are four main pharmacologic approaches for inhibition of PI3K signaling: PI3K inhibitors, AKT inhibitors, and mTOR inhibitors, and dual PI3K-mTOR inhibitors [14,91]. PI3K inhibitors can be isoform-specific or pan-PI3K inhibitors, which target all class I PI3Ks. Whether pan- or isoform-specific PI3K inhibitors will be more effective is not clear. Isoform-selective treatment may exhibit less toxicity, which means it may be tolerated at the higher doses necessary for more complete target inhibition with fewer adverse effects [92]. The realization that different PI3K isoforms play non-redundant roles in different tumor types has attracted increasing interest in isoform-specific inhibitors [93]. However, since RAS can utilize multiple PI3K isoforms, more effective suppression may require a pan-PI3K inhibitor. More work must be done to understand the mechanisms underlying drug resistance and escape of PI3K dependency following isoform-specific therapies. AKT inhibitors are typically either ATP mimetics or allosteric, non-catalytic site inhibitors. Allosteric AKT inhibitors block the attachment of AKT to the membrane by interfering with the binding of the $\mathrm{PH}$ (pleckstrin homology) domain to phosphoinositides. Mislocalization of AKT in turn diminishes its ability to signal. A potential drawback of this class of inhibitors is that they will not block the non-AKT effectors of PI3K signaling and hence paradoxically increase the PI3K-dependent activation of those effectors via the loss of negative feedback [92].

Mammalian target of rapamycin (mTOR) exists as two distinct complexes, mTOR complex 1 (mTORC1; which contains the regulatory-associated protein of TOR1 (RAPTOR)) and mTORC2 (which contains the rapamycin-insensitive companion of mTOR (RICTOR)). Rapamycin and its analogues (also known as rapalogues, which include everolimus, ridaforolimus and temsirolimus) are selective for mTORC1, forming an inactive complex with mTOR and FKBP12. Second-generation mTOR catalytic site inhibitors directly inhibit both mTOR complexes, mTORC1 and mTORC2, and are more effective inhibitors of downstream signaling and ultimately RNA translation than the first generation rapalogues [94,95]. A concern with these inhibitors is that feedback activation of PI3K from mTOR inhibition may result in hyperactivation of AKT-independent effectors of PI3K signaling [92]. Since the p110 subunits of PI3K and mTOR have similar structures, the inhibition of p110 often results in the inhibition of mTOR [96]. This dual inhibition of PI3K-mTOR is expected to shut down PI3K-AKT-mTORC1 signaling; however, it is still unclear whether a dose that sufficiently blocks cellular signaling will be tolerable.

The recent observation that downstream of PI3K, PDK1 is a key effector of oncogenic KRAS signaling in the pancreas has led to enhanced interest in specifically targeting this PI3K effector [97]. PHT-427 is a novel AKT/PDK1 pleckstrin homology domain inhibitor, which is capable of binding to both AKT and PDK1; however, inhibition of PDK1 was more closely correlated to its antitumor activity than AKT inhibition [98]. Furthermore, when PHT-427 was encapsulated in poly (lactin-co-glycolic) acid (PLGA) nanoparticles drug delivery was improved and tumor volume was reduced by $4-6$ fold in preclinical mouse models [99].

Monotherapies targeting PI3K, AKT, and/or mTOR have been largely disappointing in RAS-mutant cancers. However, in mouse models, potent synergistic activity has been observed when inhibitors of the PI3K pathway are combined with inhibitors of the RAF-MEK-ERK cascade [87]. 
Specifically, in mice with PDAC, treatment with MEK (GDC-0973) or PI3K inhibitors (GDC-0941) alone showed slight tumor growth inhibition and had no significant effect on survival. However, in comparison to the monotherapies, the combination of the two treatments resulted in a survival advantage [100]. Furthermore, combined inhibition of MEK and AKT showed synergistic activity in PDAC cell lines in vitro [101]. There are now numerous clinical trials evaluating the effect of combined inhibition of PI3K and RAF [102]. Recently, a novel approach for targeting these two pathways was described. Van Dort et al. designed a single compound that is a hybrid of the ATP competitive pan-PI3K inhibitor ZSTK474 [103] and the allosteric MEK inhibitor RO5126766 [104]. Western blot analysis showed a dose-dependent decrease of pERK and pAKT in treated PANC-1 cells, verifying the compound is cell permeable and effective [104]. Although this therapy must be optimized in order to achieve MEK and PI3K inhibition in mouse models, it is an important framework for creating a combination therapy with a single compound [104].

\section{KRAS-Regulated Metabolic Targets}

Oncogenic KRAS has been implicated in controlling a number of metabolic processes including induction of glucose uptake, unique utilization of glucose intermediates, repurposed glutamine metabolism, and increased autophagy and macropinocytosis [13]. Further elucidation of the links between oncogenic KRAS and deregulated PDAC metabolism has the potential to result in the formulation of new anti-KRAS therapies.

\subsection{Glucose Utilization and Glutamine Metabolism}

PDAC cells have altered metabolic processes consistent with increased aerobic glycolysis [105]. Interestingly, it has been demonstrated that in PDAC, mutant KRAS is responsible for orchestrating this phenotype by enhancing the expression of the glucose transporter GLUT1, as well as many other genes that encode rate-limiting glycolytic enzymes, including hexokinase I and 2 (HK1, HK2), phosphofrutokinase-1 (PFK1), and lactate dehydrogenase A (LDHA) [8]. This regulation could be exploited therapeutically by targeting LDHA, as was demonstrated using a small molecule (FX-11), which caused increased ROS production and cell death [106]. Hk2 has been identified as an attractive target for KRAS-driven lung cancers as whole-body deletion of $H k 2$ in the mouse selectively targets tumor cells [107]. The small molecule 3-bromopyruvate (3BP) inhibits Hk2 and has shown potent anticancer activity in a number of animal models [108], as well as promising results in a human case study [109]. Additionally, mutant KRAS expression leads to the shunting of glycolytic intermediates through the non-oxidative arm of the pentose phosphate pathway (PPP), which leads to the generation of ribose 5-phosphate, a necessary component for nucleic acid biosynthesis [8]. Downstream of mutant KRAS, the ERK-MAPK pathway, which culminates with the MYC transcription factor, is the major driver of glucose metabolism adjustments [8].

In addition to altered levels of glycolysis, cancer cells also display an increased dependence on glutamine [110], which contributes to cancer cell proliferation by providing carbon to fuel the tricarboxylic acid (TCA) cycle and nitrogen for nucleotide, nonessential amino acid, and hexosamine biosynthesis [111]. Glutamine is catabolized to $\alpha$-ketoglutarate $(\alpha \mathrm{KG})$, a TCA cycle intermediate, through two deamination reactions, the first requiring glutaminase (GLS) to generate glutamate and the second occurring via glutamate dehydrogenase (GDH) or transaminases. mTORC1 has been shown to positively regulate GLS and glutamine flux through this pathway through the S6K1-dependent regulation of MYC [112]. KRAS mutant PDAC has been shown to utilize glutamine metabolism to regulate redox balance by increasing the NADPH/NADP ${ }^{+}$ratio in the cell through an aspartate transaminase (GOT1)-dependent mechanism [113]. As treatment with glutamine analogs is profoundly toxic [114] the current strategy for targeting glutamine utilization as a cancer treatment, is to target those processes that cancer cells are specifically addicted to. Thus, as GOT1 is dispensable for normal cells while PDAC cells rely on this enzyme for redox homeostasis, it could be an enticing therapeutic target [113]. Additionally, two previously described GLS inhibitors Compound 968 [115] 
and bis-2-(5-phenylacetamido-1,2,4-thiadiazol-2-yl)ethyl sulfide (BPTES) [116], have demonstrated a growth suppressive effect on PDAC cells that is enhanced when combined with hydrogen peroxide treatment [113]. Finally, as inhibition of GOT1 or GLS ultimately leads to a disruption of redox homeostasis in PDAC, such inhibition may synergize with therapies that increase reactive oxygen species, such as chemotherapy and radiation [117].

\subsection{Macropinocytosis and Autophagy}

To fuel metabolic processes, KRAS signaling leads to the scavenging of extracellular proteins and lipids and activates self-eating and recycling of proteins through autophagy [118]. PDAC cells specifically expressing oncogenic KRAS utilize macropinocytosis to transport extracellular protein into the cell [119] and use it as a source of essential amino acids (EAAs) in order to sustain survival and proliferation [120]. Consistent with these studies, active macropinocytosis has been observed in primary human PDAC specimens [121]. This scavenging phenotype appears to be a general property of RAS-driven cancers as RAS-transformed cells have also been shown to scavenge lysophospholipids, which contributes to their metabolic robustness [121]. The regulation of the degradation of the EAAs taken up by macropinocytosis may shed light on the disappointing lack of efficacy of mTOR inhibitors as PDAC therapeutics. It has been demonstrated that in mammalian cells, mTORC1 signaling suppresses lysosomal catabolism of proteins that were taken up from the extracellular environment [120]. Thus, mTORC1 inhibition may enhance cell proliferation that depends on extracellular proteins, such as PDAC cells inhabiting a poorly vascularized area [120]. A specific inhibitor of macropinocytosis has yet to reach the clinic; however, preclinical studies in which heterotopic tumor bearing mice were treated with the tool compound 5 -( $N$-ethyl- $N$-isopropyl) amiloride (EIPA) showed attenuation of tumor growth and in some cases, regression [119].

Autophagy is a highly conserved mechanism to degrade intracellular components and promote the survival of stressed cells by providing energy in the form of ATP and building blocks such as amino acids, lipids, sugars, and nucleosides [122]. The role of autophagy in cancer is extremely complex [123] and while it appears clear that PDAC cells depend on autophagy for growth, the role of oncogenic KRAS in this dependence remains unclear. When tissue samples from 71 PDAC patients were analyzed via immunohistochemical staining for LC3 protein (a component of the autophagosome), it was determined that high expression was correlated with large tumor size, short-disease free period, and overall poor patient outcome [124]. Additional studies have revealed that pancreatic cancers have a clear dependence on autophagy. Genetic or pharmacological inhibition of autophagy results in increased reactive oxygen species, elevated DNA damage, and mitochondrial defects that lead to decreased proliferation of pancreatic cancer cell lines in vitro, as well as substantial tumor regression and sustained survival in in vivo models of pancreatic cancer [125,126]. In support of a cooperative role between RAS expression and proliferation fueled by autophagy, immortal, non-tumorigenic baby mouse kidney epithelial (BBMK) cells ectopically expressing oncogenic HRAS or $K R A S$ experienced defects in mitochondrial respiration upon autophagy inhibition [126]. However, a cooperative relationship between RAS and autophagy is not universally reported. For example, acute expression of oncogenic HRAS ${ }^{G 12 V}$ in immortalized human ovarian surface epithelial cells was associated with caspase-independent cell death, rather than increased proliferative capacity [127]. Furthermore, autophagy was implicated as a facilitator of RAS-induced senescence in a study in which oncogenic HRAS was overexpressed in IMR90 human diploid fibroblasts [128]. Additionally, a very recent study assayed a panel of 47 different cancer cell lines comprised of both KRAS mutant and $K R A S$ wild-type lines and found that the KRAS-mutated cells were no more dependent on autophagy than their wild-type counterparts [129]. Thus, the specific role that KRAS plays in the upregulation of autophagy in PDAC remains a controversy.

A recent study that used a mouse model of PDAC harboring an embryonic homozygous Trp53 deletion paradoxically demonstrated that loss of autophagy accelerates tumor onset [130]. However, further studies using a mouse model with Trp53 loss of heterozygosity, which is similar to TP53 
mutations in human PDAC, as well as patient-derived xenographs showed that p53 status does not affect the response of a patient to autophagy inhibition [131]. Interestingly, an inhibitor of autophagy, hydroxychloroquine (HCQ), has been available clinically for quite some time as the FDA approved it for the treatment of malaria and rheumatic disorders years ago. Hence, there are multiple early phase studies exploring the use of HCQ in as a treatment for pancreatic cancer. However, early observations have been disappointing, likely due to the limited potency of HCQ to block autophagy in vivo [132]. Notably, HCQ does not specifically inhibit autophagy, it is an inhibitor of lysosomal acidification, and thus hinders all pathways that terminate in the lysosome. Therefore, processes such as macropinocytosis are similarly inhibited with HCQ. This is supported by a recent study that found that while HCQ treatment is antiproliferative and synergizes with targeted anticancer drugs, these effects may be independent of autophagy inhibition [129].

\section{Harnessing the Immune Response}

Recent successes of cancer immunotherapy, such as antibody blockade of cytotoxic T lymphocyte antigen-4 (CTLA-4), have generated a lot of excitement, but unfortunately this form of treatment has been less successful in patients with pancreatic cancer [133]. A major barrier for immunotherapeutic approaches is thought to be profound immune suppression associated with the pancreatic tumor microenvironment [134]. It is now well understood that formation of PDAC is accompanied by pronounced alterations in stromal responses and immune surveillance programs, and there is an increasing appreciation that signaling by oncogenic RAS plays a direct role in orchestrating some of these changes in tumor microenvironment. Multiple signaling mechanisms downstream of RAS may account for this effect. Activation of oncogenic RAS has been shown to down regulate expression of major histocompatibility complexes (MHC) [135-138], resulting in decreased antigen presentation by tumor cells and reduced recognition by the immune system $[139,140]$. Oncogenic RAS has also been shown to upregulate expression of immunomodulatory cytokines, such as IL-8 and GM-CSF. Experimental perturbation in tumor-derived cytokine levels resulted in reduced inflammation and increased anti-tumor cytotoxic T cell response [141,142]. Significantly, pharmacologic inhibition of either ERK or AKT downregulated cytokine expression in KRAS transformed cells. These observations propel the hypothesis that abrogation of signaling pathways downstream of activated RAS may improve anti-tumor immune response. In support of this idea, inhibition of MEK or BRAF in melanoma correlated with reduced levels of immunosuppressive cytokines and an increase in infiltrating $\mathrm{T}$ cells [143-145]. A rational extension of this hypothesis is the idea that inhibition of RAS signaling may yield better responses to immune checkpoint blockade agents. Indeed, recent studies in TBNC featuring activation of RAS signaling pathways demonstrated that co-targeting of MEK and PD-L1 results in upregulation of MHC I and II on tumor cells and increase in CD8 T cell infiltration [146]. While inhibition of RAS-driven signaling has so far been shown to have positive immunomodulatory function, it will also be helpful to evaluate its potential effects on T cell activity [147]. Overall, strategies aimed at combining RAS-targeted therapy and immunotherapy hold significant promise as clinically feasible and effective therapeutic modalities.

PDAC is distinctive as desmoplastic stroma accounts for $70 \%-80 \%$ of the tumor volume $[148,149]$. Stromal accumulation is KRAS driven and is initiated in PanIN lesions, suggesting that its early onset is important to tumor growth and progression [150]. The dense stromal compartment is thought to prevent the delivery of drugs to the target tissue; therefore, the targeting of the stroma itself may be a way to improve current chemotherapeutics. The stroma is composed of cancer-associated fibroblasts, extracellular matrix, inflammatory cells and blood vessels [151]. Stroma and cancer cells both contribute to the extracellular matrix, which is composed of macromolecules like collagens and hyaluron and regulatory components like secreted protein acidic and rich in cytosine (SPARC) [152]. Hyaluronic acid is trapped in the interstitium of PDAC, where it can reach one of the highest concentrations found in nature [153]. Here, it absorbs water and significantly increases the interstitial fluid pressure. Targeting hyaluronic acid with hyaluronidase (PEGPH20) reduces HA, thereby reducing interstitial pressure 
and supporting drug delivery [154]. In combination with gemcitabine, PEGPH20 increased response rate, decreased metastasis and increased median survival in the KPC mouse model of PDAC [154]. Clinical trials have suggested the co-treatment provides improved progression-free survival for PDAC patients with high hyaluron expression, while increasing chances of thromboembolic events [155]. Although the pursuit of stromal depletion appears promising, other recent data suggest that the stroma could also function to protect the cancer from quickly spreading [152]. Clearly, PDAC has a unique microenvironment due to its unusual stromal content, which requires a better understanding.

\section{Conclusions}

In summary, we have highlighted six promising paths to finding an effective treatment for KRAS-mutant pancreatic cancer: targeting KRAS directly, upsetting its membrane association, exploiting synthetic lethal interactions, targeting the pathways downstream of $K R A S$, pursuing the metabolic processes that KRAS regulates, and harnessing the immune response. Although each of these approaches has shown promise in cells and even animal studies, none of these treatments have been very successful in the clinic. Thus, pancreatic cancer is projected to overcome breast cancer to become the third leading cause of cancer deaths in the U.S. in 2016 [156], and then surpass colorectal cancer to become the second leading cause of cancer deaths in the U.S. by around 2020 [157]. The major challenge with treatments that seem successful preclinically is that a patient quickly develops resistance, making combination therapies an attractive new direction. Despite the lack of clinical treatments to date, studies to better understand $R A S$ mutant cancers continue to move in promising directions, which will hopefully lead to benefits for patients with PDAC.

Acknowledgments: Kirsten L. Bryant is supported by a Pancreatic Cancer Action Network-AACR Pathway to Leadership grant (15-70-25-BRYA). Yuliya Pylayeva-Gupta is supported by a Pancreatic Cancer Action Network-AACR Pathway to Leadership grant (13-70-25-PYLA). Channing J. Der is supported by grants from the NIH (CA042978, CA179193, and CA199235), Department of Defense (CA140731), Lustgarten Foundation and the Pancreatic Cancer Action Network-AACR.

Author Contributions: Daniel Zeitouni, Yuliya Pylayeva-Gupta, Channing J. Der, and Kirsten L. Bryant contributed to the manuscript text; Daniel Zeitouni, Channing J. Der, and Kirsten L. Bryant prepared the figures; and Channing J. Der and Kirsten L. Bryant conceived the structure of the review.

Conflicts of Interest: The authors declare no conflict of interest.

\section{Abbreviations}

The following abbreviations are used in this manuscript:

$\begin{array}{ll}\text { 3BP } & \text { 3-bromopyruvate } \\ \text { BPTES } & \text { bis-2-(5-phenylacetamido-1,2,4-thiadiazol-2-yl)ethyl sulfide } \\ \text { CDK } & \text { cyclin-dependent kinase } \\ \text { CDKN2A } & \text { cyclin-dependent kinase inhibitor 2A } \\ \text { CTLA-4 } & \text { cytotoxic T lymphocyte antigen-4 } \\ \text { DOPC } & \text { 1,2-dioleoyl-sn-glycero-3-phosphatidylcholine } \\ \text { EAA } & \text { essential amino acid } \\ \text { EIPA } & \text { 5-(N-ethyl-N-isopropyl)amiloride } \\ \text { ER } & \text { Endoplasmic Reticulum } \\ \text { FBLD } & \text { fragment-based lead discovery } \\ \text { FTase } & \text { farnesyltransferase } \\ \text { FTI } & \text { farnesyl transferase inhibitor } \\ \text { FTS } & \text { farnesyl thiosalicylic acid } \\ \text { GAP } & \text { GTPase activating proteins } \\ \text { GDP } & \text { guanosine diphosphate } \\ \text { GEF } & \text { guanine nucleotide exchange factors } \\ \text { GTP } & \text { guanosine triphosphate }\end{array}$




$\begin{array}{ll}\text { HA } & \text { hyaluronic acid } \\ \text { HBS } & \text { hydrogen bond surrogate } \\ \text { HCQ } & \text { hydroxychloroquine } \\ \text { Hk1 } & \text { hexokinase 1 } \\ \text { Hk2 } & \text { hexokinase } 2 \\ \text { ICMT } & \text { isoprenylcysteine methyltransferase } \\ \text { LDHA } & \text { lactate dehydrogenase A } \\ \text { LODER } & \text { Local Drug EluteR } \\ \text { MHC } & \text { major histocompatibility complexes } \\ \text { mTOR } & \text { mammalian target of rapamycin } \\ \text { mTORC1 } & \text { mTOR complex 1 } \\ \text { mTORC2 } & \text { mTOR complex 2 } \\ \text { NSCLC } & \text { Non-small cell lung cancer } \\ \text { PanIN } & \text { pancreatic intraepithelial neoplasia } \\ \text { PDAC } & \text { Pancreatic Ductal Adenocarcinoma } \\ \text { PDE } \delta & \text { Phosphodiesterase } \delta \\ \text { Pfk1 } & \text { phosphofructokinase } \\ \text { PFS } & \text { progression free survival } \\ \text { PH } & \text { pleckstrin homology } \\ \text { PIP } 2 & \text { phosphatidylinositol 4,5-bisphosphate } \\ \text { PKC } & \text { protein kinase C } \\ \text { PPP } & \text { pentose phosphate pathway } \\ \text { RCE1 } & \text { RAS converting enzyme 1 } \\ \text { RNAi } & \text { RNA interference } \\ \text { Serine 181 } & \text { S181 } \\ \text { SOS } & \text { Son of Sevenless } \\ \text { TP53 } & \text { tumor protein 53 } \\ & \end{array}$

\section{References}

1. Ryan, D.P.; Hong, T.S.; Bardeesy, N. Pancreatic adenocarcinoma. N. Engl. J. Med. 2014, 371, $2140-2141$. [CrossRef] [PubMed]

2. Wolfgang, C.L.; Herman, J.M.; Laheru, D.A.; Klein, A.P.; Erdek, M.A.; Fishman, E.K.; Hruban, R.H. Recent progress in pancreatic cancer. CA Cancer J. Clin. 2013, 63, 318-348. [CrossRef] [PubMed]

3. Stark, A.; Hines, O.J. Endoscopic and operative palliation strategies for pancreatic ductal adenocarcinoma. Semin. Oncol. 2015, 42, 163-176. [CrossRef] [PubMed]

4. Biankin, A.V.; Waddell, N.; Kassahn, K.S.; Gingras, M.C.; Muthuswamy, L.B.; Johns, A.L.; Miller, D.K.; Wilson, P.J.; Patch, A.M.; Wu, J.; et al. Pancreatic cancer genomes reveal aberrations in axon guidance pathway genes. Nature 2012, 491, 399-405. [CrossRef] [PubMed]

5. Jones, S.; Zhang, X.; Parsons, D.W.; Lin, J.C.; Leary, R.J.; Angenendt, P.; Mankoo, P.; Carter, H.; Kamiyama, H.; Jimeno, A.; et al. Core signaling pathways in human pancreatic cancers revealed by global genomic analyses. Science 2008, 321, 1801-1806. [CrossRef] [PubMed]

6. Waddell, N.; Pajic, M.; Patch, A.M.; Chang, D.K.; Kassahn, K.S.; Bailey, P.; Johns, A.L.; Miller, D.; Nones, K.; Quek, K.; et al. Whole genomes redefine the mutational landscape of pancreatic cancer. Nature 2015, 518, 495-501. [CrossRef] [PubMed]

7. Witkiewicz, A.K.; McMillan, E.A.; Balaji, U.; Baek, G.; Lin, W.C.; Mansour, J.; Mollaee, M.; Wagner, K.U.; Koduru, P.; Yopp, A.; et al. Whole-exome sequencing of pancreatic cancer defines genetic diversity and therapeutic targets. Nat. Commun. 2015. [CrossRef] [PubMed]

8. Ying, H.; Kimmelman, A.C.; Lyssiotis, C.A.; Hua, S.; Chu, G.C.; Fletcher-Sananikone, E.; Locasale, J.W.; Son, J.; Zhang, H.; Coloff, J.L.; et al. Oncogenic Kras maintains pancreatic tumors through regulation of anabolic glucose metabolism. Cell 2012, 149, 656-670. [CrossRef] [PubMed]

9. Collins, M.A.; Bednar, F.; Zhang, Y.; Brisset, J.C.; Galbán, S.; Galbán, C.J.; Rakshit, S.; Flannagan, K.S.; Adsay, N.V.; Pasca di Magliano, M. Oncogenic Kras is required for both the initiation and maintenance of pancreatic cancer in mice. J. Clin. Investig. 2012, 122, 639-653. [CrossRef] [PubMed] 
10. Brummelkamp, T.R.; Bernards, R.; Agami, R. Stable suppression of tumorigenicity by virus-mediated RNA interference. Cancer Cell 2002, 2, 243-247. [CrossRef]

11. Abbruzzese, J.L. Pancreatic cancer: Scanning the horizon for focused interventions. Available online: http:/ / deainfo.nci.nih.gov/advisory/ctac/archive/0313/PCwgReport.pdf 1-22 (accessed on 5 January 2016).

12. Stephen, A.G.; Esposito, D.; Bagni, R.K.; McCormick, F. Dragging RAS back in the ring. Cancer Cell 2014, 25, 272-281. [CrossRef] [PubMed]

13. Bryant, K.L.; Mancias, J.D.; Kimmelman, A.C.; Der, C.J. KRAS: Feeding pancreatic cancer proliferation. Trends Biochem. Sci. 2014, 39, 91-100. [CrossRef] [PubMed]

14. Cox, A.D.; Fesik, S.W.; Kimmelman, A.C.; Luo, J.; Der, C.J. Drugging the undruggable RAS: Mission possible? Nat. Rev. Drug Discov. 2014, 13, 828-851. [CrossRef] [PubMed]

15. Tsai, F.D.; Lopes, M.S.; Zhou, M.; Court, H.; Ponce, O.; Fiordalisi, J.J.; Gierut, J.J.; Cox, A.D.; Haigis, K.M.; Philips, M.R. K-Ras4A splice variant is widely expressed in cancer and uses a hybrid membrane-targeting motif. Proc. Natl. Acad. Sci. USA 2015, 112, 779-784. [CrossRef] [PubMed]

16. Cox, A.D.; Der, C.J.; Philips, M.R. Targeting RAS Membrane Association: Back to the Future for Anti-RAS Drug Discovery? Clin. Cancer Res. 2015, 21, 1819-1827. [CrossRef] [PubMed]

17. Vigil, D.; Cherfils, J.; Rossman, K.L.; Der, C.J. RAS superfamily GEFs and GAPs: Validated and tractable targets for cancer therapy? Nat. Rev. Cancer 2010, 10, 842-857. [CrossRef] [PubMed]

18. Prior, I.A.; Lewis, P.D.; Mattos, C. A comprehensive survey of RAS mutations in cancer. Cancer Res. 2012, 72, 2457-2467. [CrossRef] [PubMed]

19. Cox, A.D.; Der, C.J. Ras history: The saga continues. Small GTPases 2010, 1, 2-27. [CrossRef] [PubMed]

20. Scheffzek, K.; Ahmadian, M.R.; Kabsch, W.; Wiesmüller, L.; Lautwein, A.; Schmitz, F.; Wittinghofer, A. The Ras-RasGAP complex: Structural basis for GTPase activation and its loss in oncogenic RAS mutants. Science 1997, 277, 333-338. [CrossRef] [PubMed]

21. Scheidig, A.J.; Burmester, C.; Goody, R.S. The pre-hydrolysis state of p21 (RAS) in complex with GTP: New insights into the role of water molecules in the GTP hydrolysis reaction of ras-like proteins. Structure 1999, 7, 1311-1324. [CrossRef]

22. Kanda, M.; Matthaei, H.; Wu, J.; Hong, S.M.; Yu, J.; Borges, M.; Hruban, R.H.; Maitra, A.; Kinzler, K.; Vogelstein, B.; Goggins, M. Presence of somatic mutations in most early-stage pancreatic intraepithelial neoplasia. Gastroenterology 2012, 142, 730-733. [CrossRef] [PubMed]

23. Hong, S.M.; Vincent, A.; Kanda, M.; Leclerc, J.; Omura, N.; Borges, M.; Klein, A.P.; Canto, M.I.; Hruban, R.H.; Goggins, M. Genome-wide somatic copy number alterations in low-grade PanINs and IPMNs from individuals with a family history of pancreatic cancer. Clin. Cancer Res. 2012, 18, 4303-4312. [CrossRef] [PubMed]

24. Vincent, A.; Herman, J.; Schulick, R.; Hruban, R.H.; Goggins, M. Pancreatic cancer. Lancet 2011, 378, 607-620. [CrossRef]

25. Schutte, M.; Hruban, R.H.; Geradts, J.; Maynard, R.; Hilgers, W.; Rabindran, S.K.; Moskaluk, C.A.; Hahn, S.A.; Schwarte-Waldhoff, I.; Schmiegel, W.; et al. Abrogation of the Rb/p16 tumor-suppressive pathway in virtually all pancreatic carcinomas. Cancer Res. 1997, 57, 3126-3130. [PubMed]

26. Malkoski, S.P.; Wang, X.J. Two sides of the story? Smad4 loss in pancreatic cancer versus head-and-neck cancer. FEBS Lett. 2012, 586, 1984-1992. [CrossRef] [PubMed]

27. Sun, Q.; Burke, J.P.; Phan, J.; Burns, M.C.; Olejniczak, E.T.; Waterson, A.G.; Lee, T.; Rossanese, O.W.; Fesik, S.W. Discovery of small molecules that bind to K-Ras and inhibit Sos-mediated activation. Angew. Chem. Int. Ed. Engl. 2012, 51, 6140-6143. [CrossRef] [PubMed]

28. Maurer, T.; Garrenton, L.S.; Oh, A.; Pitts, K.; Anderson, D.J.; Skelton, N.J.; Fauber, B.P.; Pan, B.; Malek, S.; Stokoe, D.; et al. Small-molecule ligands bind to a distinct pocket in Ras and inhibit SOS-mediated nucleotide exchange activity. Proc. Natl. Acad. Sci. USA 2012, 109, 5299-5304. [CrossRef] [PubMed]

29. Burns, M.C.; Sun, Q.; Daniels, R.N.; Camper, D.; Kennedy, J.P.; Phan, J.; Olejniczak, E.T.; Lee, T.; Waterson, A.G.; Rossanese, O.W.; et al. Approach for targeting Ras with small molecules that activate SOS-mediated nucleotide exchange. Proc. Natl. Acad. Sci. USA 2014, 111, 3401-3406. [CrossRef] [PubMed]

30. Shima, F.; Yoshikawa, Y.; Ye, M.; Araki, M.; Matsumoto, S.; Liao, J.; Hu, L.; Sugimoto, T.; Ijiri, Y.; Takeda, A.; et al. In silico discovery of small-molecule Ras inhibitors that display antitumor activity by blocking the Ras-effector interaction. Proc. Natl. Acad. Sci. USA 2013, 110, 8182-8187. [CrossRef] [PubMed] 
31. Ostrem, J.M.; Peters, U.; Sos, M.L.; Wells, J.A.; Shokat, K.M. K-RAS (G12C) inhibitors allosterically control GTP affinity and effector interactions. Nature 2013, 503, 548-551. [CrossRef] [PubMed]

32. Lim, S.M.; Westover, K.D.; Ficarro, S.B.; Harrison, R.A.; Choi, H.G.; Pacold, M.E.; Carrasco, M.; Hunter, J.; Kim, N.D.; Xie, T.; et al. Therapeutic targeting of oncogenic K-RAS by a covalent catalytic site inhibitor. Angew. Chem. Int. Ed. Engl. 2014, 53, 199-204. [CrossRef] [PubMed]

33. Yuan, T.L.; Fellmann, C.; Lee, C.S.; Ritchie, C.D.; Thapar, V.; Lee, L.C.; Hsu, D.J.; Grace, D.; Carver, J.O.; Zuber, J.; et al. Development of siRNA payloads to target KRAS-mutant cancer. Cancer Discov. 2014, 4, 1182-1197. [CrossRef] [PubMed]

34. Xue, W.; Dahlman, J.E.; Tammela, T.; Khan, O.F.; Sood, S.; Dave, A.; Cai, W.; Chirino, L.M.; Yang, G.R.; Bronson, R.; et al. Small RNA combination therapy for lung cancer. Proc. Natl. Acad. Sci. USA 2014, 111, 3553-3661. [CrossRef] [PubMed]

35. Lim, K.H.; Counter, C.M. Reduction in the requirement of oncogenic RAS signaling to activation of PI3K/AKT pathway during tumor maintenance. Cancer Cell 2005, 8, 381-392. [CrossRef] [PubMed]

36. Fleming, J.B.; Shen, G.L.; Holloway, S.E.; Davis, M.; Brekken, R.A. Molecular consequences of silencing mutant K-RAS in pancreatic cancer cells: Justification for K-RAS-directed therapy. Mol. Cancer Res. 2005, 3, 413-423. [CrossRef] [PubMed]

37. Zorde Khvalevsky, E.; Gabai, R.; Rachmut, I.H.; Horwitz, E.; Brunschwig, Z.; Orbach, A.; Shemi, A.; Golan, T.; Domb, A.J.; Yavin, E.; et al. Mutant KRAS is a druggable target for pancreatic cancer. Proc. Natl. Acad. Sci. USA 2013, 110, 20723-20728. [CrossRef] [PubMed]

38. Golan, T.; Khvalevsky, E.Z.; Hubert, A.; Gabai, R.M.; Hen, N.; Segal, A.; Domb, A.; Harari, G.; David, E.B.; Raskin, S.; et al. RNAi therapy targeting KRAS in combination with chemotherapy for locally advanced pancreatic cancer patients. Oncotarget 2015, 6, 24560-24570. [CrossRef] [PubMed]

39. Pecot, C.V.; Wu, S.Y.; Bellister, S.; Filant, J.; Rupaimoole, R.; Hisamatsu, T.; Bhattacharya, R.; Maharaj, A.; Azam, S.; Rodriguez-Aguayo, C.; et al. Therapeutic silencing of KRAS using systemically delivered siRNAs. Mol. Cancer Ther. 2014, 13, 2876-2885. [CrossRef] [PubMed]

40. Ahearn, I.M.; Haigis, K.; Bar-Sagi, D.; Philips, M.R. Regulating the regulator: Post-translational modification of RAS. Nat. Rev. Mol. Cell Biol. 2012, 13, 39-51. [CrossRef] [PubMed]

41. Basso, A.D.; Kirschmeier, P.; Bishop, W.R. Lipid posttranslational modifications. Farnesyl transferase inhibitors. J. Lipid Res. 2006, 47, 15-31. [CrossRef] [PubMed]

42. Berndt, N.; Hamilton, A.D.; Sebti, S.M. Targeting protein prenylation for cancer therapy. Nat. Rev. Cancer 2011, 11, 775-791. [CrossRef] [PubMed]

43. Macdonald, J.S.; McCoy, S.; Whitehead, R.P.; Iqbal, S.; Wade, J.L.; Giguere, J.K.; Abbruzzese, J.L. A phase II study of farnesyl transferase inhibitor R115777 in pancreatic cancer: A Southwest oncology group (SWOG 9924) study. Investig. New Drugs 2005, 23, 485-487. [CrossRef] [PubMed]

44. Cohen, S.J.; Ho, L.; Ranganathan, S.; Abbruzzese, J.L.; Alpaugh, R.K.; Beard, M.; Lewis, N.L.; McLaughlin, S.; Rogatko, A.; Perez-Ruixo, J.J.; et al. Phase II and pharmacodynamic study of the farnesyltransferase inhibitor R115777 as initial therapy in patients with metastatic pancreatic adenocarcinoma. J. Clin. Oncol. 2003, 21, 1301-1306. [CrossRef] [PubMed]

45. Van Cutsem, E.; van de Velde, H.; Karasek, P.; Oettle, H.; Vervenne, W.L.; Szawlowski, A.; Schoffski, P.; Post, S.; Verslype, C.; Neumann, H.; et al. Phase III trial of gemcitabine plus tipifarnib compared with gemcitabine plus placebo in advanced pancreatic cancer. J. Clin. Oncol. 2004, 22, 1430-1438. [CrossRef] [PubMed]

46. Blum, R.; Cox, A.D.; Kloog, Y. Inhibitors of chronically active ras: Potential for treatment of human malignancies. Recent Pat. Anticancer Drug Discov. 2008, 3, 31-47. [PubMed]

47. Haklai, R.; Weisz, M.G.; Elad, G.; Paz, A.; Marciano, D.; Egozi, Y.; Ben-Baruch, G.; Kloog, Y. Dislodgment and accelerated degradation of Ras. Biochemistry 1998, 37, 1306-1314. [CrossRef] [PubMed]

48. Marom, M.; Haklai, R.; Ben-Baruch, G.; Marciano, D.; Egozi, Y.; Kloog, Y. Selective inhibition of Ras-dependent cell growth by farnesylthiosalisylic acid. J. Biol. Chem. 1995, 270, 22263-22270. [CrossRef] [PubMed]

49. Riely, G.J.; Johnson, M.L.; Medina, C.; Rizvi, N.A.; Miller, V.A.; Kris, M.G.; Pietanza, M.C.; Azzoli, C.G.; Krug, L.M.; Pao, W.; et al. A phase II trial of Salirasib in patients with lung adenocarcinomas with KRAS mutations. J. Thorac. Oncol. 2011, 6, 1435-1437. [CrossRef] [PubMed] 
50. Chandra, A.; Grecco, H.E.; Pisupati, V.; Perera, D.; Cassidy, L.; Skoulidis, F.; Ismail, S.A.; Hedberg, C.; Hanzal-Bayer, M.; Venkitaraman, A.R.; et al. The GDI-like solubilizing factor PDE $\delta$ sustains the spatial organization and signaling of Ras family proteins. Nat. Cell Biol. 2012, 14, 148-158. [CrossRef] [PubMed]

51. Zimmermann, G.; Papke, B.; Ismail, S.; Vartak, N.; Chandra, A.; Hoffmann, M.; Hahn, S.A.; Triola, G.; Wittinghofer, A.; Bastiaens, P.I.; et al. Small molecule inhibition of the KRAS-PDE $\delta$ interaction impairs oncogenic KRAS signalling. Nature 2013, 497, 638-642. [CrossRef] [PubMed]

52. Fehrenbacher, N.; Bar-Sagi, D.; Philips, M. Ras/MAPK signaling from endomembranes. Mol. Oncol. 2009, 3 , 297-307. [CrossRef] [PubMed]

53. Bivona, T.G.; Quatela, S.E.; Bodemann, B.O.; Ahearn, I.M.; Soskis, M.J.; Mor, A.; Miura, J.; Wiener, H.H.; Wright, L.; Saba, S.G.; et al. PKC regulates a farnesyl-electrostatic switch on K-Ras that promotes its association with Bcl-XL on mitochondria and induces apoptosis. Mol. Cell 2006, 21, 481-493. [CrossRef] [PubMed]

54. Sung, P.J.; Tsai, F.D.; Vais, H.; Court, H.; Yang, J.; Fehrenbacher, N.; Foskett, J.K.; Philips, M.R. Phosphorylated K-Ras limits cell survival by blocking Bcl-xL sensitization of inositol trisphosphate receptors. Proc. Natl. Acad. Sci. USA 2013, 110, 20593-20598. [CrossRef] [PubMed]

55. Barceló, C.; Paco, N.; Morell, M.; Alvarez-Moya, B.; Bota-Rabassedas, N.; Jaumot, M.; Vilardell, F.; Capella, G.; Agell, N. Phosphorylation at Ser-181 of oncogenic KRAS is required for tumor growth. Cancer Res. 2014, 74, 1190-1199. [CrossRef] [PubMed]

56. Mohammad, R.M.; Dugan, M.C.; Mohamed, A.N.; Almatchy, V.P.; Flake, T.M.; Dergham, S.T.; Shields, A.F.; Al-Katib, A.A.; Vaitkevicius, V.K.; Sarkar, F.H. Establishment of a human pancreatic tumor xenograft model: Potential application for preclinical evaluation of novel therapeutic agents. Pancreas 1998, 16, 19-25. [CrossRef] [PubMed]

57. Mohammad, R.M.; Limvarapuss, C.; Hamdy, N.; Dutcher, B.S.; Beck, F.W.; Wall, N.R.; Al-Katib, A.M. Treatment of a de novo fludarabine resistant-CLL xenograft model with bryostatin 1 followed by fludarabine. Int. J. Oncol. 1999, 14, 945-950. [CrossRef] [PubMed]

58. Kollár, P.; Rajchard, J.; Balounová, Z.; Pazourek, J. Marine natural products: Bryostatins in preclinical and clinical studies. Pharm. Biol. 2014, 52, 237-242. [CrossRef] [PubMed]

59. Schwartsmann, G.; Brondani da Rocha, A.; Berlinck, R.G.; Jimeno, J. Marine organisms as a source of new anticancer agents. Lancet Oncol. 2001, 2, 221-225. [CrossRef]

60. Hanahan, D.; Weinberg, R.A. Hallmarks of cancer: The next generation. Cell 2011, 144, 646-674. [CrossRef] [PubMed]

61. Luo, J.; Solimini, N.L.; Elledge, S.J. Principles of cancer therapy: Oncogene and non-oncogene addiction. Cell 2009, 136, 823-837. [CrossRef] [PubMed]

62. Tamanoi, F.; Der, C.J. Inhibitors of the Ras superfamily of small G-proteins. Preface. Enzymes 2013. [CrossRef]

63. Sarthy, A.V.; Morgan-Lappe, S.E.; Zakula, D.; Vernetti, L.; Schurdak, M.; Packer, J.C.; Anderson, M.G.; Shirasawa, S.; Sasazuki, T.; Fesik, S.W. Survivin depletion preferentially reduces the survival of activated K-Ras-transformed cells. Mol. Cancer Ther. 2007, 6, 269-276. [CrossRef] [PubMed]

64. Morgan-Lappe, S.E.; Tucker, L.A.; Huang, X.; Zhang, Q.; Sarthy, A.V.; Zakula, D.; Vernetti, L.; Schurdak, M.; Wang, J.; Fesik, S.W. Identification of Ras-related nuclear protein, targeting protein for xenopus kinesin-like protein 2, and stearoyl-CoA desaturase 1 as promising cancer targets from an RNAi-based screen. Cancer Res. 2007, 67, 4390-4398. [CrossRef] [PubMed]

65. Steckel, M.; Molina-Arcas, M.; Weigelt, B.; Marani, M.; Warne, P.H.; Kuznetsov, H.; Kelly, G.; Saunders, B.; Howell, M.; Downward, J.; et al. Determination of synthetic lethal interactions in KRAS oncogene-dependent cancer cells reveals novel therapeutic targeting strategies. Cell Res. 2012, 22, 1227-1245. [CrossRef] [PubMed]

66. Kumar, M.S.; Hancock, D.C.; Molina-Arcas, M.; Steckel, M.; East, P.; Diefenbacher, M.; Armenteros-Monterroso, E.; Lassailly, F.; Matthews, N.; Nye, E.; et al. The GATA2 transcriptional network is requisite for RAS oncogene-driven non-small cell lung cancer. Cell 2012, 149, 642-655. [CrossRef] [PubMed]

67. Scholl, C.; Fröhling, S.; Dunn, I.F.; Schinzel, A.C.; Barbie, D.A.; Kim, S.Y.; Silver, S.J.; Tamayo, P.; Wadlow, R.C.; Ramaswamy, S.; et al. Synthetic lethal interaction between oncogenic KRAS dependency and STK33 suppression in human cancer cells. Cell 2009, 137, 821-834. [CrossRef] [PubMed]

68. Luo, T.; Masson, K.; Jaffe, J.D.; Silkworth, W.; Ross, N.T.; Scherer, C.A.; Scholl, C.; Fröhling, S.; Carr, S.A.; Stern, A.M.; et al. STK33 kinase inhibitor BRD-8899 has no effect on KRAS-dependent cancer cell viability. Proc. Natl. Acad. Sci. USA 2012, 109, 2860-2865. [CrossRef] [PubMed] 
69. Barbie, D.A.; Tamayo, P.; Boehm, J.S.; Kim, S.Y.; Moody, S.E.; Dunn, I.F.; Schinzel, A.C.; Sandy, P.; Meylan, E.; Scholl, C.; et al. Systematic RNA interference reveals that oncogenic KRAS-driven cancers require TBK1. Nature 2009, 462, 108-112. [CrossRef] [PubMed]

70. Muvaffak, A.; Pan, Q.; Yan, H.; Fernandez, R.; Lim, J.; Dolinski, B.; Nguyen, T.T.; Strack, P.; Wu, S.; Chung, R.; et al. Evaluating TBK1 as a therapeutic target in cancers with activated IRF3. Mol. Cancer Res. 2014, 12, 1055-1066. [CrossRef] [PubMed]

71. Hayes, T.K.; Neel, N.F.; Hu, C.; Gautam, P.; Chenard, M.; Long, B.; Aziz, M.; Kassner, M.; Bryant, K.L.; Pierobon, M.; et al. Long-Term ERK Inhibition in KRAS-Mutant Pancreatic Cancer Is Associated with MYC Degradation and Senescence-like Growth Suppression. Cancer Cell 2016, 29, 75-89. [CrossRef] [PubMed]

72. Anderson, S.N.; Towne, D.L.; Burns, D.J.; Warrior, U. A high-throughput soft agar assay for identification of anticancer compound. J. Biomol. Screen. 2007, 12, 938-945. [CrossRef] [PubMed]

73. Meacham, C.E.; Ho, E.E.; Dubrovsky, E.; Gertler, F.B.; Hemann, M.T. In vivo RNAi screening identifies regulators of actin dynamics as key determinants of lymphoma progression. Nat. Genet. 2009, 41, 1133-1137. [CrossRef] [PubMed]

74. Possemato, R.; Marks, K.M.; Shaul, Y.D.; Pacold, M.E.; Kim, D.; Birsoy, K.; Sethumadhavan, S.; Woo, H.K.; Jang, H.G.; Jha, A.K.; et al. Functional genomics reveal that the serine synthesis pathway is essential in breast cancer. Nature 2011, 476, 346-350. [CrossRef] [PubMed]

75. Baines, A.T.; Xu, D.; Der, C.J. Inhibition of Ras for cancer treatment: The search continues. Future Med. Chem. 2011, 3, 1787-1808. [CrossRef] [PubMed]

76. Yoon, S.; Seger, R. The extracellular signal-regulated kinase: Multiple substrates regulate diverse cellular functions. Growth Factors 2006, 24, 21-44. [CrossRef] [PubMed]

77. Roskoski, R. ERK1/2 MAP kinases: Structure, function, and regulation. Pharmacol. Res. 2012, 66, 105-143. [CrossRef] [PubMed]

78. Hatzivassiliou, G.; Song, K.; Yen, I.; Brandhuber, B.J.; Anderson, D.J.; Alvarado, R.; Ludlam, M.J.; Stokoe, D.; Gloor, S.L.; Vigers, G.; et al. RAF inhibitors prime wild-type RAF to activate the MAPK pathway and enhance growth. Nature 2010, 464, 431-435. [CrossRef] [PubMed]

79. Heidorn, S.J.; Milagre, C.; Whittaker, S.; Nourry, A.; Niculescu-Duvas, I.; Dhomen, N.; Hussain, J.; Reis-Filho, J.S.; Springer, C.J.; Pritchard, C.; et al. Kinase-dead BRAF and oncogenic RAS cooperate to drive tumor progression through CRAF. Cell 2010, 140, 209-221. [CrossRef] [PubMed]

80. Poulikakos, P.I.; Zhang, C.; Bollag, G.; Shokat, K.M.; Rosen, N. RAF inhibitors transactivate RAF dimers and ERK signalling in cells with wild-type BRAF. Nature 2010, 464, 427-430. [CrossRef] [PubMed]

81. Samatar, A.A.; Poulikakos, P.I. Targeting RAS-ERK signalling in cancer: Promises and challenges. Nat. Rev. Drug Discov. 2014, 13, 928-942. [CrossRef] [PubMed]

82. Ryan, M.B.; Der, C.J.; Wang-Gillam, A.; Cox, A.D. Targeting RAS-mutant Cancers: Is ERK the Key? Trends Cancer 2015, 1, 183-198. [CrossRef] [PubMed]

83. Peng, S.B.; Henry, J.R.; Kaufman, M.D.; Lu, W.P.; Smith, B.D.; Vogeti, S.; Rutkoski, T.J.; Wise, S.; Chun, L.; Zhang, Y.; et al. Inhibition of RAF Isoforms and Active Dimers by LY3009120 Leads to Anti-tumor Activities in RAS or BRAF Mutant Cancers. Cancer Cell 2015, 28, 384-398. [CrossRef] [PubMed]

84. Zhang, C.; Spevak, W.; Zhang, Y.; Burton, E.A.; Ma, Y.; Habets, G.; Zhang, J.; Lin, J.; Ewing, T.; Matusow, B.; et al. RAF inhibitors that evade paradoxical MAPK pathway activation. Nature 2015, 526, 583-586. [CrossRef] [PubMed]

85. Lugowska, I.; Koseła-Paterczyk, H.; Kozak, K.; Rutkowski, P. Trametinib: A MEK inhibitor for management of metastatic melanoma. Onco. Targets Ther. 2015, 8, 2251-2259. [PubMed]

86. Gilmartin, A.G.; Bleam, M.R.; Groy, A.; Moss, K.G.; Minthorn, E.A.; Kulkarni, S.G.; Rominger, C.M.; Erskine, S.; Fisher, K.E.; Yang, J.; et al. GSK1120212 (JTP-74057) is an inhibitor of MEK activity and activation with favorable pharmacokinetic properties for sustained in vivo pathway inhibition. Clin. Cancer Res. 2011, 17, 989-1000. [CrossRef] [PubMed]

87. Engelman, J.A.; Chen, L.; Tan, X.; Crosby, K.; Guimaraes, A.R.; Upadhyay, R.; Maira, M.; McNamara, K.; Perera, S.A.; Song, Y.; et al. Effective use of PI3K and MEK inhibitors to treat mutant Kras G12D and PIK3CA H1047R murine lung cancers. Nat. Med. 2008, 14, 1351-1356. [CrossRef] [PubMed]

88. Hatzivassiliou, G.; Haling, J.R.; Chen, H.; Song, K.; Price, S.; Heald, R.; Hewitt, J.F.; Zak, M.; Peck, A.; Orr, C.; et al. Mechanism of MEK inhibition determines efficacy in mutant KRAS- versus BRAF-driven cancers. Nature 2013, 501, 232-236. [CrossRef] [PubMed] 
89. Duncan, J.S.; Whittle, M.C.; Nakamura, K.; Abell, A.N.; Midland, A.A.; Zawistowski, J.S.; Johnson, N.L.; Granger, D.A.; Jordan, N.V.; Darr, D.B.; et al. Dynamic reprogramming of the kinome in response to targeted MEK inhibition in triple-negative breast cancer. Cell 2012, 149, 307-321. [CrossRef] [PubMed]

90. Morris, E.J.; Jha, S.; Restaino, C.R.; Dayananth, P.; Zhu, H.; Cooper, A.; Carr, D.; Deng, Y.; Jin, W.; Black, S.; et al. Discovery of a novel ERK inhibitor with activity in models of acquired resistance to BRAF and MEK inhibitors. Cancer Discov. 2013, 3, 742-750. [CrossRef] [PubMed]

91. Fruman, D.A.; Rommel, C. PI3K and cancer: Lessons, challenges and opportunities. Nat. Rev. Drug Discov. 2014, 13, 140-156. [CrossRef] [PubMed]

92. Engelman, J.A. Targeting PI3K signalling in cancer: Opportunities, challenges and limitations. Nat. Rev. Cancer 2009, 9, 550-562. [CrossRef] [PubMed]

93. Wang, X.; Ding, J.; Meng, L.H. PI3K isoform-selective inhibitors: Next-generation targeted cancer therapies. Acta Pharmacol. Sin. 2015, 36, 1170-1176. [CrossRef] [PubMed]

94. Feldman, M.E.; Apsel, B.; Uotila, A.; Loewith, R.; Knight, Z.A.; Ruggero, D.; Shokat, K.M. Active-site inhibitors of mTOR target rapamycin-resistant outputs of mTORC1 and mTORC2. PLoS Biol. 2009. [CrossRef] [PubMed]

95. Thoreen, C.C.; Kang, S.A.; Chang, J.W.; Liu, Q.; Zhang, J.; Gao, Y.; Reichling, L.J.; Sim, T.; Sabatini, D.M.; Gray, N.S. An ATP-competitive mammalian target of rapamycin inhibitor reveals rapamycin-resistant functions of mTORC1. J. Biol. Chem. 2009, 284, 8023-8032. [CrossRef] [PubMed]

96. Garcia-Echeverria, C.; Sellers, W.R. Drug discovery approaches targeting the PI3K/Akt pathway in cancer. Oncogene 2008, 27, 5511-5526. [CrossRef] [PubMed]

97. Eser, S.; Reiff, N.; Messer, M.; Seidler, B.; Gottschalk, K.; Dobler, M.; Hieber, M.; Arbeiter, A.; Klein, S.; Kong, B.; et al. Selective requirement of PI3K/PDK1 signaling for Kras oncogene-driven pancreatic cell plasticity and cancer. Cancer Cell 2013, 23, 406-420. [CrossRef] [PubMed]

98. Meuillet, E.J.; Zuohe, S.; Lemos, R.; Ihle, N.; Kingston, J.; Watkins, R.; Moses, S.A.; Zhang, S.; Du-Cuny, L.; Herbst, R.; et al. Molecular pharmacology and antitumor activity of PHT-427, a novel Akt/phosphatidylinositide-dependent protein kinase 1 pleckstrin homology domain inhibitor. Mol. Cancer Ther. 2010, 9, 706-717. [CrossRef] [PubMed]

99. Kobes, J.E.; Daryaei, I.; Howison, C.M.; Bontrager, J.G.; Sirianni, R.W.; Meuillet, E.J.; Pagel, M.D. Improved Treatment of Pancreatic Cancer With Drug Delivery Nanoparticles Loaded With a Novel AKT/PDK1 Inhibitor. Pancreas 2016. [CrossRef] [PubMed]

100. Junttila, M.R.; Devasthali, V.; Cheng, J.H.; Castillo, J.; Metcalfe, C.; Clermont, A.C.; Otter, D.D.; Chan, E.; Bou-Reslan, H.; Cao, T.; et al. Modeling targeted inhibition of MEK and PI3 kinase in human pancreatic cancer. Mol. Cancer Ther. 2015, 14, 40-47. [CrossRef] [PubMed]

101. Collisson, E.A.; Trejo, C.L.; Silva, J.M.; Gu, S.; Korkola, J.E.; Heiser, L.M.; Charles, R.P.; Rabinovich, B.A.; Hann, B.; Dankort, D.; et al. A central role for RAF $\rightarrow$ MEK $\rightarrow$ ERK signaling in the genesis of pancreatic ductal adenocarcinoma. Cancer Discov. 2012, 2, 685-693. [CrossRef] [PubMed]

102. Britten, C.D. PI3K and MEK inhibitor combinations: Examining the evidence in selected tumor types. Cancer Chemother. Pharmacol. 2013, 71, 1395-1409. [CrossRef] [PubMed]

103. Kong, D.; Yamori, T. ZSTK474 is an ATP-competitive inhibitor of class I phosphatidylinositol 3 kinase isoforms. Cancer Sci. 2007, 98, 1638-1642. [CrossRef] [PubMed]

104. Van Dort, M.E.; Galbán, S.; Wang, H.; Sebolt-Leopold, J.; Whitehead, C.; Hong, H.; Rehemtulla, A.; Ross, B.D. Dual inhibition of allosteric mitogen-activated protein kinase (MEK) and phosphatidylinositol 3-kinase (PI3K) oncogenic targets with a bifunctional inhibitor. Bioorg. Med. Chem. 2015, 23, 1386-1394. [CrossRef] [PubMed]

105. Zhou, W.; Capello, M.; Fredolini, C.; Racanicchi, L.; Piemonti, L.; Liotta, L.A.; Novelli, F.; Petricoin, E.F. Proteomic analysis reveals Warburg effect and anomalous metabolism of glutamine in pancreatic cancer cells. J. Proteome Res. 2012, 11, 554-563. [CrossRef] [PubMed]

106. Le, A.; Cooper, C.R.; Gouw, A.M.; Dinavahi, R.; Maitra, A.; Deck, L.M.; Royer, R.E.; Vander Jagt, D.L.; Semenza, G.L.; Dang, C.V. Inhibition of lactate dehydrogenase A induces oxidative stress and inhibits tumor progression. Proc. Natl. Acad. Sci. USA 2010, 107, 2037-2042. [CrossRef] [PubMed]

107. Patra, K.C.; Wang, Q.; Bhaskar, P.T.; Miller, L.; Wang, Z.; Wheaton, W.; Chandel, N.; Laakso, M.; Muller, W.J.; Allen, E.L.; et al. Hexokinase 2 is required for tumor initiation and maintenance and its systemic deletion is therapeutic in mouse models of cancer. Cancer Cell 2013, 24, 213-228. [CrossRef] [PubMed] 
108. Ko, Y.H.; Smith, B.L.; Wang, Y.; Pomper, M.G.; Rini, D.A.; Torbenson, M.S.; Hullihen, J.; Pedersen, P.L. Advanced cancers: Eradication in all cases using 3-bromopyruvate therapy to deplete ATP. Biochem. Biophys. Res. Commun. 2004, 324, 269-275. [CrossRef] [PubMed]

109. Ko, Y.H.; Verhoeven, H.A.; Lee, M.J.; Corbin, D.J.; Vogl, T.J.; Pedersen, P.L. A translational study "case report" on the small molecule "energy blocker" 3-bromopyruvate (3BP) as a potent anticancer agent: From bench side to bedside. J. Bioenerg. Biomembr. 2012, 44, 163-170. [CrossRef] [PubMed]

110. Wise, D.R.; Thompson, C.B. Glutamine addiction: A new therapeutic target in cancer. Trends Biochem. Sci. 2010, 35, 427-433. [CrossRef] [PubMed]

111. Hensley, C.T.; Wasti, A.T.; DeBerardinis, R.J. Glutamine and cancer: Cell biology, physiology, and clinical opportunities. J. Clin. Investig. 2013, 123, 3678-3684. [CrossRef] [PubMed]

112. Csibi, A.; Lee, G.; Yoon, S.O.; Tong, H.; Ilter, D.; Elia, I.; Fendt, S.M.; Roberts, T.M.; Blenis, J. The mTORC1/S6K1 pathway regulates glutamine metabolism through the eIF4B-dependent control of c-Myc translation. Curr. Biol. 2014, 24, 2274-2280. [CrossRef] [PubMed]

113. Son, J.; Lyssiotis, C.A.; Ying, H.; Wang, X.; Hua, S.; Ligorio, M.; Perera, R.M.; Ferrone, C.R.; Mullarky, E.; Shyh-Chang, N.; et al. Glutamine supports pancreatic cancer growth through a KRAS-regulated metabolic pathway. Nature 2013, 496, 101-105. [CrossRef] [PubMed]

114. Ahluwalia, G.S.; Grem, J.L.; Hao, Z.; Cooney, D.A. Metabolism and action of amino acid analog anti-cancer agents. Pharmacol. Ther. 1990, 46, 243-271. [CrossRef]

115. Wang, J.B.; Erickson, J.W.; Fuji, R.; Ramachandran, S.; Gao, P.; Dinavahi, R.; Wilson, K.F.; Ambrosio, A.L.; Dias, S.M.; Dang, C.V.; et al. Targeting mitochondrial glutaminase activity inhibits oncogenic transformation. Cancer Cell 2010, 18, 207-219. [CrossRef] [PubMed]

116. Robinson, M.M.; McBryant, S.J.; Tsukamoto, T.; Rojas, C.; Ferraris, D.V.; Hamilton, S.K.; Hansen, J.C.; Curthoys, N.P. Novel mechanism of inhibition of rat kidney-type glutaminase by bis-2-(5-phenylacetamido-1,2,4-thiadiazol-2-yl)ethyl sulfide (BPTES). Biochem. J. 2007, 406, 407-414. [CrossRef] [PubMed]

117. Lyssiotis, C.A.; Son, J.; Cantley, L.C.; Kimmelman, A.C. Pancreatic cancers rely on a novel glutamine metabolism pathway to maintain redox balance. Cell Cycle 2013, 12, 1987-1988. [CrossRef] [PubMed]

118. White, E. Exploiting the bad eating habits of Ras-driven cancers. Genes Dev. 2013, 27, 2065-2071. [CrossRef] [PubMed]

119. Commisso, C.; Davidson, S.M.; Soydaner-Azeloglu, R.G.; Parker, S.J.; Kamphorst, J.J.; Hackett, S.; Grabocka, E.; Nofal, M.; Drebin, J.A.; Thompson, C.B.; et al. Macropinocytosis of protein is an amino acid supply route in Ras-transformed cells. Nature 2013, 497, 633-637. [CrossRef] [PubMed]

120. Palm, W.; Park, Y.; Wright, K.; Pavlova, N.N.; Tuveson, D.A.; Thompson, C.B. The utilization of extracellular proteins as nutrients is suppressed by mTORC1. Cell 2015, 162, 259-270. [CrossRef] [PubMed]

121. Kamphorst, J.J.; Nofal, M.; Commisso, C.; Hackett, S.R.; Lu, W.; Grabocka, E.; Vander Heiden, M.G.; Miller, G.; Drebin, J.A.; Bar-Sagi, D.; et al. Human pancreatic cancer tumors are nutrient poor and tumor cells actively scavenge extracellular protein. Cancer Res. 2015, 75, 544-553. [CrossRef] [PubMed]

122. Rabinowitz, J.D.; White, E. Autophagy and metabolism. Science 2010, 330, 1344-1348. [CrossRef] [PubMed]

123. Hippert, M.M.; O'Toole, P.S.; Thorburn, A. Autophagy in cancer: Good, bad, or both? Cancer Res. 2006, 66, 9349-9351. [CrossRef] [PubMed]

124. Fujii, S.; Mitsunaga, S.; Yamazaki, M.; Hasebe, T.; Ishii, G.; Kojima, M.; Kinoshita, T.; Ueno, T.; Esumi, H.; Ochiai, A. Autophagy is activated in pancreatic cancer cells and correlates with poor patient outcome. Cancer Sci. 2008, 99, 1813-1819. [CrossRef] [PubMed]

125. Yang, S.; Wang, X.; Contino, G.; Liesa, M.; Sahin, E.; Ying, H.; Bause, A.; Li, Y.; Stommel, J.M.; Dell'antonio, G.; et al. Pancreatic cancers require autophagy for tumor growth. Genes Dev. 2011, 25, 717-729. [CrossRef] [PubMed]

126. Guo, J.Y.; Chen, H.Y.; Mathew, R.; Fan, J.; Strohecker, A.M.; Karsli-Uzunbas, G.; Kamphorst, J.J.; Chen, G.; Lemons, J.M.; Karantza, V.; et al. Activated Ras requires autophagy to maintain oxidative metabolism and tumorigenesis. Genes Dev. 2011, 25, 460-470. [CrossRef] [PubMed]

127. Elgendy, M.; Sheridan, C.; Brumatti, G.; Martin, S.J. Oncogenic Ras-induced expression of Noxa and Beclin-1 promotes autophagic cell death and limits clonogenic survival. Mol. Cell 2011, 42, 23-35. [CrossRef] [PubMed] 
128. Young, A.R.; Narita, M.; Ferreira, M.; Kirschner, K.; Sadaie, M.; Darot, J.F.; Tavaré, S.; Arakawa, S.; Shimizu, S.; Watt, F.M.; et al. Autophagy mediates the mitotic senescence transition. Genes Dev. 2009, 23, 798-803. [CrossRef] [PubMed]

129. Eng, C.H.; Wang, Z.; Tkach, D.; Toral-Barza, L.; Ugwonali, S.; Liu, S.; Fitzgerald, S.L.; George, E.; Frias, E.; Cochran, N.; et al. Macroautophagy is dispensable for growth of KRAS mutant tumors and chloroquine efficacy. Proc. Natl. Acad. Sci. USA 2016, 113, 182-187. [CrossRef] [PubMed]

130. Rosenfeldt, M.T.; O'Prey, J.; Morton, J.P.; Nixon, C.; MacKay, G.; Mrowinska, A.; Au, A.; Rai, T.S.; Zheng, L.; Ridgway, R.; et al. p53 status determines the role of autophagy in pancreatic tumour development. Nature 2013, 504, 296-300. [CrossRef] [PubMed]

131. Yang, A.; Rajeshkumar, N.V.; Wang, X.; Yabuuchi, S.; Alexander, B.M.; Chu, G.C.; Hoff Von, D.D.; Maitra, A.; Kimmelman, A.C. Autophagy is critical for pancreatic tumor growth and progression in tumors with p53 alterations. Cancer Discov. 2014, 4, 905-913. [CrossRef] [PubMed]

132. Wolpin, B.M.; Rubinson, D.A.; Wang, X.; Chan, J.A.; Cleary, J.M.; Enzinger, P.C.; Fuchs, C.S.; McCleary, N.J.; Meyerhardt, J.A.; Ng, K.; et al. Phase II and pharmacodynamic study of autophagy inhibition using hydroxychloroquine in patients with metastatic pancreatic adenocarcinoma. Oncologist 2014, 19, 637-638. [CrossRef] [PubMed]

133. Royal, R.E.; Levy, C.; Turner, K.; Mathur, A.; Hughes, M.; Kammula, U.S.; Sherry, R.M.; Topalian, S.L.; Yang, J.C.; Lowy, I.; et al. Phase 2 trial of single agent Ipilimumab (anti-CTLA-4) for locally advanced or metastatic pancreatic adenocarcinoma. J. Immunother. 2010, 33, 828-833. [CrossRef] [PubMed]

134. Vonderheide, R.H.; Bayne, L.J. Inflammatory networks and immune surveillance of pancreatic carcinoma. Curr. Opin. Immunol. 2013, 25, 200-205. [CrossRef] [PubMed]

135. Lohmann, S.; Wollscheid, U.; Huber, C.; Seliger, B. Multiple levels of MHC class I down-regulation by RAS oncogenes. Scand. J. Immunol. 1996, 43, 537-544. [CrossRef] [PubMed]

136. Seliger, B.; Harders, C.; Wollscheid, U.; Staege, M.S.; Reske-Kunz, A.B.; Huber, C. Suppression of MHC class I antigens in oncogenic transformants: Association with decreased recognition by cytotoxic T lymphocytes. Exp. Hematol. 1996, 24, 1275-1279. [PubMed]

137. Seliger, B.; Harders, C.; Lohmann, S.; Momburg, F.; Urlinger, S.; Tampé, R.; Huber, C. Down-regulation of the MHC class I antigen-processing machinery after oncogenic transformation of murine fibroblasts. Eur. J. Immunol. 1998, 28, 122-133. [CrossRef]

138. Delp, K.; Momburg, F.; Hilmes, C.; Huber, C.; Seliger, B. Functional deficiencies of components of the MHC class I antigen pathway in human tumors of epithelial origin. Bone Marrow Transplant. 2000, 25, 88-95. [CrossRef]

139. Maudsley, D.J.; Bateman, W.J.; Morris, A.G. Reduced stimulation of helper T cells by Ki-RAS transformed cells. Immunology 1991, 72, 277-281. [PubMed]

140. Testorelli, C.; Bussini, S.; De Filippi, R.; Marelli, O.; Orlando, L.; Greiner, J.W.; Grohmann, U.; Tentori, L.; Giuliani, A.; Bonmassar, E.; et al. Dacarbazine-induced immunogenicity of a murine leukemia is attenuated in cells transfected with mutated K-ras gene. J. Exp. Clin. Cancer Res. 1997, 16, 15-22. [PubMed]

141. Sparmann, A.; Bar-Sagi, D. Ras-induced interleukin-8 expression plays a critical role in tumor growth and angiogenesis. Cancer Cell 2004, 6, 447-458. [CrossRef] [PubMed]

142. Pylayeva-Gupta, Y.; Lee, K.E.; Hajdu, C.H.; Miller, G.; Bar-Sagi, D. Oncogenic Kras-induced GM-CSF production promotes the development of pancreatic neoplasia. Cancer Cell 2012, 21, 836-847. [CrossRef] [PubMed]

143. Wilmott, J.S.; Long, G.V.; Howle, J.R.; Haydu, L.E.; Sharma, R.N.; Thompson, J.F.; Kefford, R.F.; Hersey, P.; Scolyer, R.A. Selective BRAF inhibitors induce marked T-cell infiltration into human metastatic melanoma. Clin. Cancer Res. 2012, 18, 1386-1394. [CrossRef] [PubMed]

144. Donia, M.; Fagone, P.; Nicoletti, F.; Andersen, R.S.; Høgdall, E.; Straten, P.T.; Andersen, M.H.; Svane, I.M. BRAF inhibition improves tumor recognition by the immune system: Potential implications for combinatorial therapies against melanoma involving adoptive T-cell transfer. Oncoimmunology 2012, 1, 1476-1483. [CrossRef] [PubMed]

145. Liu, C.; Peng, W.; Xu, C.; Lou, Y.; Zhang, M.; Wargo, J.A.; Chen, J.Q.; Li, H.S.; Watowich, S.S.; Yang, Y.; et al. BRAF inhibition increases tumor infiltration by $\mathrm{T}$ cells and enhances the antitumor activity of adoptive immunotherapy in mice. Clin. Cancer Res. 2013, 19, 393-403. [CrossRef] [PubMed] 
146. Loi, S.; Dushyanthen, S.; Beavis, P.A.; Salgado, R.; Denkert, C.; Savas, P.; Combs, S.; Rimm, D.L.; Giltnane, J.M.; Estrada, M.V.; et al. RAS/MAPK Activation Is Associated with Reduced Tumor-Infiltrating Lymphocytes in Triple-Negative Breast Cancer: Therapeutic Cooperation Between MEK and PD-1/PD-L1 Immune Checkpoint Inhibitors. Clin. Cancer Res. 2016, 22, 1499-1509. [CrossRef] [PubMed]

147. Liu, L.; Mayes, P.A.; Eastman, S.; Shi, H.; Yadavilli, S.; Zhang, T.; Yang, J.; Seestaller-Wehr, L.; Zhang, S.Y.; Hopson, C.; et al. The BRAF and MEK Inhibitors Dabrafenib and Trametinib: Effects on Immune Function and in Combination with Immunomodulatory Antibodies Targeting PD-1, PD-L1, and CTLA-4. Clin. Cancer Res. 2015, 21, 1639-1651. [CrossRef] [PubMed]

148. Erkan, M.; Adler, G.; Apte, M.V.; Bachem, M.G.; Buchholz, M.; Detlefsen, S.; Esposito, I.; Friess, H.; Gress, T.M.; Habisch, H.J.; et al. Stella TUM: Current consensus and discussion on pancreatic stellate cell research. Gut 2012, 61, 172-178. [CrossRef] [PubMed]

149. Hwang, R.F.; Moore, T.; Arumugam, T.; Ramachandran, V.; Amos, K.D.; Rivera, A.; Ji, B.; Evans, D.B.; Logsdon, C.D. Cancer-associated stromal fibroblasts promote pancreatic tumor progression. Cancer Res. 2008, 68, 918-926. [CrossRef] [PubMed]

150. Erkan, M. Understanding the stroma of pancreatic cancer: Co-evolution of the microenvironment with epithelial carcinogenesis. J. Pathol. 2013, 231, 4-7. [CrossRef] [PubMed]

151. Kadaba, R.; Birke, H.; Wang, J.; Hooper, S.; Andl, C.D.; Di Maggio, F.; Soylu, E.; Ghallab, M.; Bor, D.; Froeling, F.E.; et al. Imbalance of desmoplastic stromal cell numbers drives aggressive cancer processes. J. Pathol. 2013, 230, 107-117. [CrossRef] [PubMed]

152. Javle, M.; Golan, T.; Maitra, A. Changing the course of pancreatic cancer-Focus on recent translational advances. Cancer Treat. Rev. 2016, 44, 17-25. [CrossRef] [PubMed]

153. Fraser, J.R.; Laurent, T.C.; Laurent, U.B. Hyaluronan: Its nature, distribution, functions and turnover. J. Intern. Med. 1997, 242, 27-33. [CrossRef] [PubMed]

154. Provenzano, P.P.; Cuevas, C.; Chang, A.E.; Goel, V.K.; Hoff Von, D.D.; Hingorani, S.R. Enzymatic targeting of the stroma ablates physical barriers to treatment of pancreatic ductal adenocarcinoma. Cancer Cell 2012, 21, 418-429. [CrossRef] [PubMed]

155. Hingorani, S.R.; Harris, W.P.; Beck, J.T.; Berdov, B.A.; Wagner, S.A.; Pshevlotsky, E.M.; Tjulandin, S.; Gladkov, O.; Holcombe, R.F.; Korn, R.; et al. Phase 1b Study of PEGylated Recombinant Human Hyaluronidase and Gemcitabine in Patients with Advanced Pancreatic Cancer. Clin. Cancer Res. 2016. [CrossRef] [PubMed]

156. Siegel, R.L.; Miller, K.D.; Jemal, A. Cancer statistics, 2016. CA Cancer J. Clin. 2016, 66, 7-30. [CrossRef] [PubMed]

157. Rahib, L.; Smith, B.D.; Aizenberg, R.; Rosenzweig, A.B.; Fleshman, J.M.; Matrisian, L.M. Projecting cancer incidence and deaths to 2030: The unexpected burden of thyroid, liver, and pancreas cancers in the United States. Cancer Res. 2014, 74, 2913-2921. [CrossRef] [PubMed]

(C) 2016 by the authors; licensee MDPI, Basel, Switzerland. This article is an open access article distributed under the terms and conditions of the Creative Commons Attribution (CC-BY) license (http:/ / creativecommons.org/licenses/by/4.0/). 